Nat. Hazards Earth Syst. Sci., 21, 417-437, 2021

https://doi.org/10.5194/nhess-21-417-2021

(C) Author(s) 2021. This work is distributed under the Creative Commons Attribution 4.0 License.

\title{
Assessing the impact of explosive eruptions of Fogo volcano (São Miguel, Azores) on the tourism economy
}

\author{
Joana Medeiros $^{1,2}$, Rita Carmo ${ }^{1,2}$, Adriano Pimentel ${ }^{1,2,3}$, José Cabral Vieira ${ }^{4}$, and Gabriela Queiroz ${ }^{1,2}$ \\ ${ }^{1}$ Centro de Informação e Vigilância Sismovulcânica dos Açores (CIVISA), \\ 9500-321 Ponta Delgada, Portugal \\ ${ }^{2}$ Instituto de Investigação em Vulcanologia e Avaliação de Riscos (IVAR), Universidade dos Açores, 9500-321 Ponta \\ Delgada, Portugal \\ ${ }^{3}$ Centro de Investigação em Biodiversidade e Recursos Genéticos (CIBIO), InBIO Laboratório Associado, \\ Pólo dos Açores, 9500-321 Ponta Delgada, Portugal \\ ${ }^{4}$ Faculdade de Economia e Gestão da Universidade dos Açores, Universidade dos Açores, 9500-321 Ponta Delgada, Portugal
}

Correspondence: Joana Medeiros (joana.fc.medeiros@azores.gov.pt)

Received: 23 July 2020 - Discussion started: 4 August 2020

Revised: 11 December 2020 - Accepted: 11 December 2020 - Published: 29 January 2021

\begin{abstract}
The Azores are an active volcanic region that offers exceptional conditions for nature-based tourism, one of the main axes of economic growth in the archipelago. A future volcanic eruption may have long-term consequences to this economic sector. Therefore, it is fundamental to assess its vulnerability to volcanic hazards in order to try to mitigate the associated risk. This study proposes a new approach to assessing the economic impact of explosive eruptions on the tourism sector. We considered two eruptive scenarios for Fogo volcano (São Miguel Island), the most probable (Volcanic Explosivity Index, VEI, 4 sub-Plinian eruption) and the worst-case (VEI 5 Plinian eruption), both producing tephra fallout and pyroclastic density currents. The results of numerical simulations were overlaid with tourism-related buildings and infrastructure of Vila Franca do Campo municipality to identify the elements at risk. The loss present value method was used to estimate the benefits generated by the accommodation units over 30 years for different economic scenarios. The assessment of the economic impact using 2018 indicators reveals that in a near-total-destruction scenario, the economic loss is approximately EUR 145 million (considering a $2 \%$ discount rate). This approach can also be applied to other volcanic regions, geologic hazards and economic sectors.
\end{abstract}

\section{Introduction}

Among all natural phenomena on Earth, explosive volcanic eruptions are one of the most destructive and can cause major socio-economic impacts. Explosive eruptions can affect large areas of land, ocean and airspace, threatening people, animals, buildings, infrastructure, transportation, communications, agriculture land and water resources (e.g. Guffanti et al., 2005; Spence et al., 2005; Wilson et al., 2012; Scaini et al., 2014; Wilson et al., 2014; Craig et al., 2016; Brown et al., 2017; Kueppers et al., 2019). In more extreme cases, explosive eruptions may also affect global climate (e.g. Rampino and Self, 1982; Hansen et al., 1992).

Despite the numerous hazards related to explosive volcanism, in several places volcanoes are regarded as attractions and not as a potential sources of problems. For some communities, nature-based tourism plays a significant role in the development of the local economy. However, the potential of some volcanoes to produce hazardous explosive eruptions is often overlooked or underestimated.

The 1995 eruption of Soufrière Hills volcano, on Montserrat island (Lesser Antilles), is a dramatic example of the major impact that a volcanic eruption can have on a local community. This long-lasting eruption led to the island's largest migratory outbreak, with approximately $70 \%$ of the population leaving Montserrat (Kokelaar, 2002; Annen and Wagner, 2003; Hicks and Few, 2015). Before 1995, Montserrat had 
a prosperous tourism industry, with revenues accounting for approximately $25 \%$ of the island's gross domestic product (GDP) (Caribbean Community Secretariat, 2009, in Pacheco and Lewis-Cameron, 2010). The eruption had a significant impact in this sector, with a decrease of roughly $50 \%$ in arrivals between 1995 and 1996, reaching an all-time low in the following year, with a decrease of $44 \%$ relative to 1996 . The stabilisation of the volcanic activity in 1998 led to a $50 \%$ increase in arrivals compared to 1997. Although the eruption caused the destruction of critical infrastructure, including the airport and harbour, and the capacity to accommodate tourists, this sector has recovered steadily, as shown by the increase in tourist arrivals in 1997 and 1999, from 5000 visitors to approximately 10 000, respectively (Pacheco and Lewis-Cameron, 2010). Even though the last significant activity occurred in 2010, officially it is still considered an ongoing eruption (Wadge et al., 2014; Hicks and Few, 2015); yet tourism continues to grow, with Soufrière Hills volcano representing the island's most important geological monument (Pacheco and Lewis-Cameron, 2010).

Taking another perspective, the 2010 eruption of Eyjafjallajökull volcano (Iceland) drew attention to the vulnerability of modern society to the atmospheric dispersal of ash plumes. The peculiar characteristics of this eruption combined with specific meteorological conditions resulted in the dispersal of volcanic ash over large areas of the North Atlantic Ocean and Europe (e.g. Gasteiger et al., 2011; Gudmundsson et al., 2012). Despite the moderate size and duration of the eruption, it caused unprecedented disruption to civil aviation over European airspace, with more than 8.5 million passengers stranded (Alexander, 2013). The aviation sector is extremely important to the global economy since it represents $0.7 \%$ of the world's GDP and $35 \%$ of world trade (Pálsson, 2010). The overall GDP loss resulting from the longterm incapacity to move people and assets was estimated at approximately USD 4.7 billion, including airline industry losses and economic losses at touristic destinations as well as general productivity losses (Oxford Economics, 2010; Pallister and McNutt, 2015). Although locally this eruption had a reduced impact, statistical data estimate that between April and May 2010 the number of tourists decreased by approximately $17.5 \%$ in Iceland (Jónsdóttir, 2011).

Oceanic islands are particularly vulnerable to volcanic eruptions and other geological hazards due to their typical remote location, small size and rough topography, which, combined with high population densities and weak economies, make risk management and evacuation very challenging (e.g. Pelling and Uitto, 2001; Clare et al., 2018; Kueppers et al., 2019; Pimentel et al., 2020). The Azores islands (North Atlantic Ocean) have an extensive geological record of explosive volcanic eruptions that typically occur at trachytic central volcanoes (Pimentel et al., 2015). Although the frequency of large explosive eruptions is relatively low, the impact of a future explosive eruption could be devastating, with long-term consequences to the regional economy. As the
Azorean tourism underwent a significant boost since 2015 with the alteration of the accessibility and mobility model, the importance of this sector in the regional economy has grown over the years. Therefore, it is fundamental to assess its vulnerability to volcanic hazards in order to implement appropriate mitigation strategies.

São Miguel Island is the largest $\left(744 \mathrm{~km}^{2}\right)$ and most populated (> 137000 inhabitants) of the Azores archipelago, where most of the tourism industry is concentrated. The volcanic history of São Miguel shows that it is the most active island in the Azores, with the highest eruptive frequency of explosive events. At least 34 explosive eruptions (subPlinian and Plinian) are known to have occurred in the last 5000 years. Fogo volcano, located in the central part of São Miguel, was the only volcano that produced a Plinian eruption in this time frame, although it has the lowest eruptive frequency of the three active central volcanoes of the island (Gaspar et al., 2015a). Nonetheless, its potential to produce hazardous explosive eruptions must not be underestimated, and the economic impact of future eruptions should be properly assessed.

In this framework, we aim to evaluate the impact of future explosive eruptions of Fogo volcano on the tourism of São Miguel, taking Vila Franca do Campo municipality as a study area. To assess which areas and exposed elements are susceptible to being affected by tephra fallout and pyroclastic density currents (PDCs), two eruptive scenarios were considered: the most probable scenario, corresponding to a sub-Plinian eruption with a Volcanic Explosivity Index (VEI; Newhall and Self, 1982) of 4, and the worst-case scenario, corresponding to a Plinian eruption with VEI 5. The assessment was carried out on buildings related to tourism and allowed the estimation of which exposed elements could be affected, with physical damage and loss of functionality. The methodology proposed consists of evaluating the benefits generated by the tourism industry, restricted to the quantification of revenues generated by accommodation units, to determine the current loss of that revenue over 30 years. Such analysis is especially important as tourism is a growing and promising activity in the Azores in general (Vieira et al., 2019); on São Miguel Island (Vieira and Antunes, 2017); and certainly in Vila Franca do Campo, which due to the existence of bathing areas, a moderate climate, and maritime and recreational infrastructures attracts many visitors. This study represents the first attempt to quantify the economic loss related to future explosive eruptions of Fogo volcano on the island of São Miguel. However, the present approach may be adopted to other active volcanic regions and economic activities.

\section{Geographical and geological setting}

The Azores archipelago is located in the North Atlantic Ocean and comprises nine volcanic islands. From a geody- 
namic point of view, this region corresponds to the triple junction where the North American, Eurasian and Nubian lithospheric plates meet (Fig. 1a, b). Due to this particular geodynamic framework, the archipelago is subject to frequent seismic and volcanic activity (e.g. Gaspar et al., 2015b).

São Miguel Island is formed by three active central volcanoes - Sete Cidades, Fogo and Furnas - linked by Picos and Congro fissure volcanic systems. The eastern part of the island comprises the older and inactive Povoação volcano and Nordeste volcanic system (Fig. 1c). All three active central volcanoes are truncated by summit calderas related to paroxysmal explosive eruptions. In the last 5000 years at least 33 sub-Plinian eruptions and one Plinian eruption are known to have occurred on São Miguel (Pacheco et al., 2013; Gaspar et al., 2015a).

Located in the central part of São Miguel, Fogo volcano (also known as Água de Pau volcano) is the largest of the three active central volcanoes of the island, reaching a maximum altitude of $947 \mathrm{~m}$ above sea level. The $3.2 \mathrm{~km}$ wide summit caldera was formed by several collapse events and is presently occupied by a lake. Several volcanic structures are present inside the caldera (lava domes, pumice and tuff cones) as well as on the northern and southern flanks of the volcano (lava domes, scoria and pumice cones) (Wallenstein, 1999; Wallenstein et al., 2015).

The stratigraphy of Fogo volcano is divided into two major lithostratigraphic units (Wallenstein, 1999; Wallenstein et al., 2015): the Lower Group, which comprises all volcanic products older than $40 \mathrm{ka}$, and the Upper Group, which includes all products emitted in the last $40 \mathrm{kyr}$, including from the historical eruptions. The recent eruptive period was marked by at least two paroxysmal explosive eruptions of Plinian dimensions: the Ribeira Chã eruption (8000-12 000 years ago) and the Fogo A eruption ( $\sim 600$ years ago). In particular, the last 5000 years were characterised by five sub-Plinian eruptions: Pisão and Fogo B, C, D and 1563 (historic).

Fogo A was one of the largest eruptions recorded on São Miguel. Its deposit encompasses a complex and widespread succession of trachytic pyroclastic products emitted from the summit caldera (e.g. Walker and Croasdale, 1971; Booth et al., 1978; Bursik et al., 1992; Wallenstein, 1999; Pensa et al., 2015a, b). The eruption started with a short-lived hydromagmatic phase, followed by a Plinian eruptive column that produced a major pumice fall deposit. The radial and almost-symmetrical distribution of the fall deposit indicates that weak wind was blowing from the west during the eruption. The eruptive column experienced partial collapses that generated small-volume PDCs, and, in the final stage, the total collapse of the column led to the emplacement of a voluminous ignimbrite, reaching $>20 \mathrm{~m}$ thick in Ribeira Grande graben (Wallenstein, 1999; Pensa et al., 2015a, b; Wallenstein et al., 2015).

The last sub-Plinian eruption of Fogo volcano occurred in CE 1563. The deposit corresponds to a stratified succession of trachytic pumice lapilli and ash fall layers (e.g. Walker and Croasdale, 1971; Booth et al., 1978; Wallenstein, 1999; Aguiar, 2018). The eruption started on 28 June in the centre of the caldera, on a previously existing cone (know as Pico da Lagoinha or Pico das Berlengas) (Frutuoso, 1981). The first phase was hydromagmatic and was followed by a sub-Plinian eruptive column with repeated hydromagmatic pulses. Tephra was mostly dispersed to the eastern part of the island due to the strong west-south-west-blowing wind (Walker and Croasdale, 1971; Wallenstein, 1999; Aguiar, 2018). The eruptive activity lasted $5 \mathrm{~d}$ and ceased on 3 July; $4 \mathrm{~d}$ after the onset of the sub-Plinian eruption, a basaltic flank eruption occurred on Pico Queimado dome (then called Pico do Sapateiro), on the north flank of Fogo volcano. A subsequent phreatic explosion was also reported inside the caldera on 10 February 1564 (Frutuoso, 1981; Wallenstein et al., 2015; Aguiar, 2018).

The present study area, Vila Franca do Campo municipality, is located on the southern flank of Fogo volcano, and it borders with Lagoa municipality to the west, Ribeira Grande to the north and Povoação to the east. To the south it is bounded by the ocean in a costal extension of $15.5 \mathrm{~km}$. Vila Franca do Campo has an area of $77.9 \mathrm{~km}^{2}$ and is divided in six parishes: Água d'Alto, São Pedro, São Miguel, Ribeira Seca, Ribeira das Tainhas and Ponta Garça (Fig. 2).

\section{Methodology}

\subsection{Definition of the eruptive scenarios}

The first step in the assessment of the impact of future explosive eruptions of Fogo volcano on São Miguel Island was to define the eruptive scenarios. Based on the recent geological record of Fogo volcano (last 5000 years) and the frequency and magnitude of past trachytic explosive eruptions, two scenarios were defined: the most probable scenario (i.e. the most likely eruption) and the worst-case scenario (i.e. the largest-magnitude eruption), in agreement with previous studies (e.g. Gaspar et al., 2015a). The most probable scenario is a sub-Plinian eruption with VEI 4, similar to the Fogo 1563 eruption. Such an eruption would produce widespread tephra fallout and could also generate PDCs in proximal areas, although this was not the case of the 1563 eruption. The worst-case scenario is a Plinian eruption with VEI 5, similar to the Fogo A eruption. Such an eruption would produce thick widespread tephra fallout and generate voluminous PDCs along the flanks of the volcano.

Taking into account that in the Azores region there are differences in the wind patterns of summer (May to September) and winter periods (October to April) (see wind statistical analysis in Pimentel et al., 2006; Cole et al., 2008; Gaspar et al., 2015a), different tephra fallout scenarios should also be considered for the two periods. 

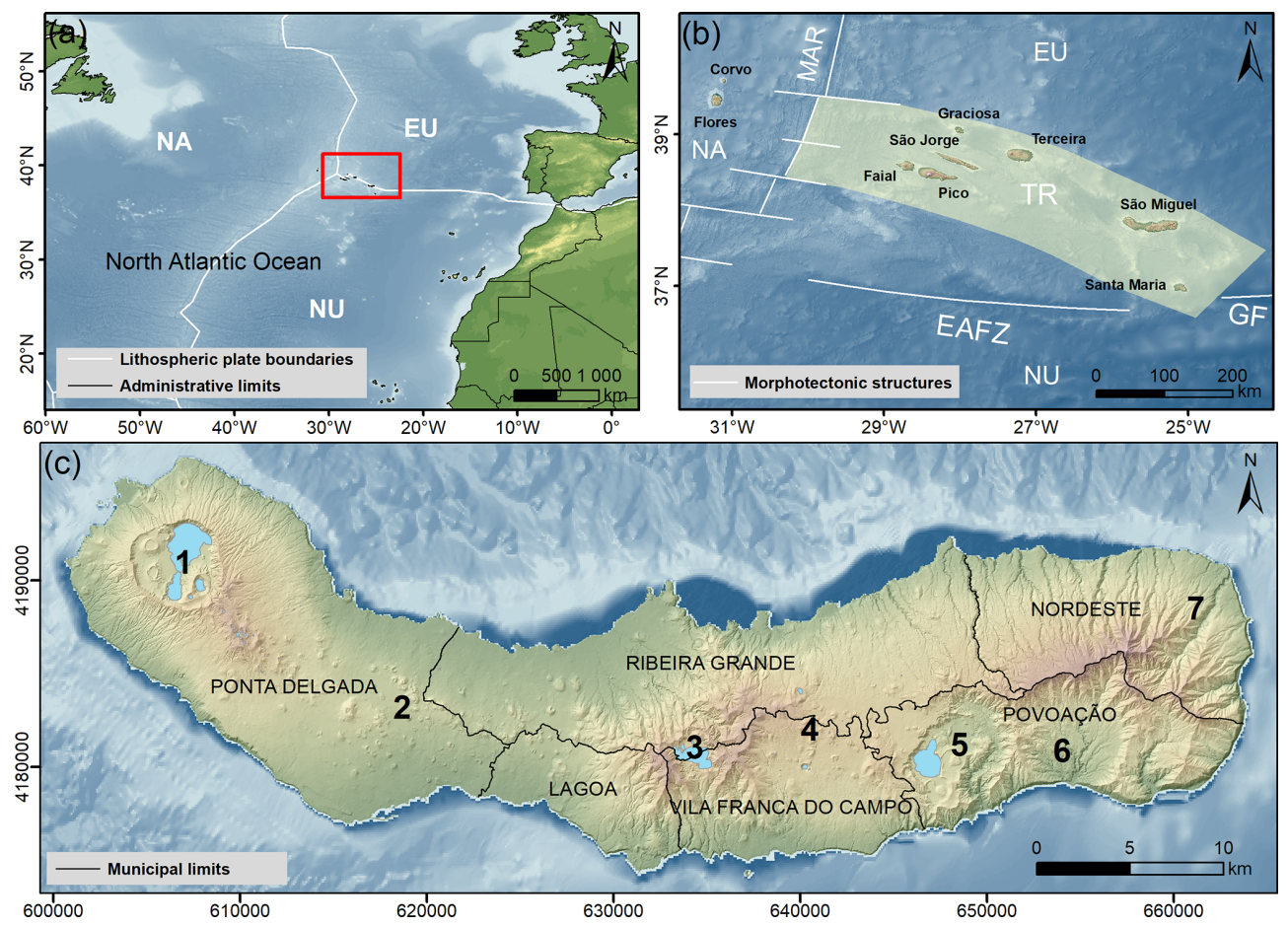

Figure 1. (a) Location of the Azores archipelago in the North Atlantic Ocean and relation to the triple junction between the North American (NA), Eurasian (EU) and Nubian (NU) lithospheric plates (world bathymetry and topography from the GEBCO_08 Grid; plate and country boundaries from the Environmental Systems Research Institute, ESRI). Geographic coordinates: datum WGS 84. (b) Geodynamic setting of the Azores archipelago and main morphotectonic structures of the region. MAR: Mid-Atlantic Ridge; TR: Terceira Rift; EAFZ: East Azores Fracture Zone; GF: Gloria Fault (Azores bathymetry from EMODnet Bathymetry Consortium, 2018; morphotectonic structures modified from Hipólito et al., 2010). Geographic coordinates: datum WGS 84. (c) Digital elevation model of São Miguel Island showing the volcanic systems and administrative limits of the six municipalities: (1) Sete Cidades volcano, (2) Picos fissure volcanic system, (3) Fogo volcano, (4) Congro fissure volcanic system, (5) Furnas volcano, (6) Povoação volcano, (7) Nordeste volcanic system (after Gaspar et al., 2015a). UTM coordinates, zone 26S, datum WGS 84.

\subsection{Numerical simulations}

To identify which areas of São Miguel are susceptible to being affected by trachytic explosive eruptions of Fogo volcano, the dispersion of tephra fallout and PDCs was simulated using VORIS (Volcanic Risk Information System) version 2.0.1 (Felpeto et al., 2007) implemented in a geographic information system (GIS) (ArcGIS 9.1 ESRI ${ }^{\circledR}$ ). VORIS 2.0.1 is a tool used in the assessment of volcanic hazards that provides users with the necessary instruments for the production of scenarios and hazard maps.

\subsubsection{Tephra fallout}

Numerical simulations of tephra fallout were computed using an advection-diffusion model that assumes that above the vent the mass is distributed along a vertical line following the Suzuki approach (Suzuki, 1983). Far from the vent, the transport of particles is controlled by the advective effect of the wind, the diffusion due to atmosphere turbulence and the terminal settling velocity of the particles (see details in Folch and Felpeto, 2005; Felpeto et al., 2007).
The eruptive source parameters used in the simulations were obtained from the literature related to the Fogo A and Fogo 1563 eruptions and, when unavailable, from published data of similar explosive eruptions. For the most probable scenario (a VEI 4 sub-Plinian eruption), we considered a total bulk volume of $1 \mathrm{~km}^{3}$ (Booth et al., 1978) and a column height of $18500 \mathrm{~m}$ (Carey and Sparks, 1986). For the worstcase scenario (a VEI 5 Plinian eruption), we used a total bulk volume of $3.2 \mathrm{~km}^{3}$ (Booth et al., 1978) and a column height of $27000 \mathrm{~m}$ (Bursik et al., 1992). The simulations were conducted assuming a vent located in the centre of Fogo caldera. Eruptive input parameters are shown in Table 1.

Wind parameters were compiled by Pimentel et al. (2006) from the Integrated Global Radiosonde Archive dataset of the National Centers for Environmental Information, formerly the National Climatic Data Center (https://www.ncdc.noaa.gov/data-access/weather-balloon/ integrated-global-radiosonde-archive, last access: 8 December 2020), for the Lajes station, on the neighbouring island of Terceira, between 1947 and 2003. Statistical analysis of 56 years of radiosonde data revealed significant differences 


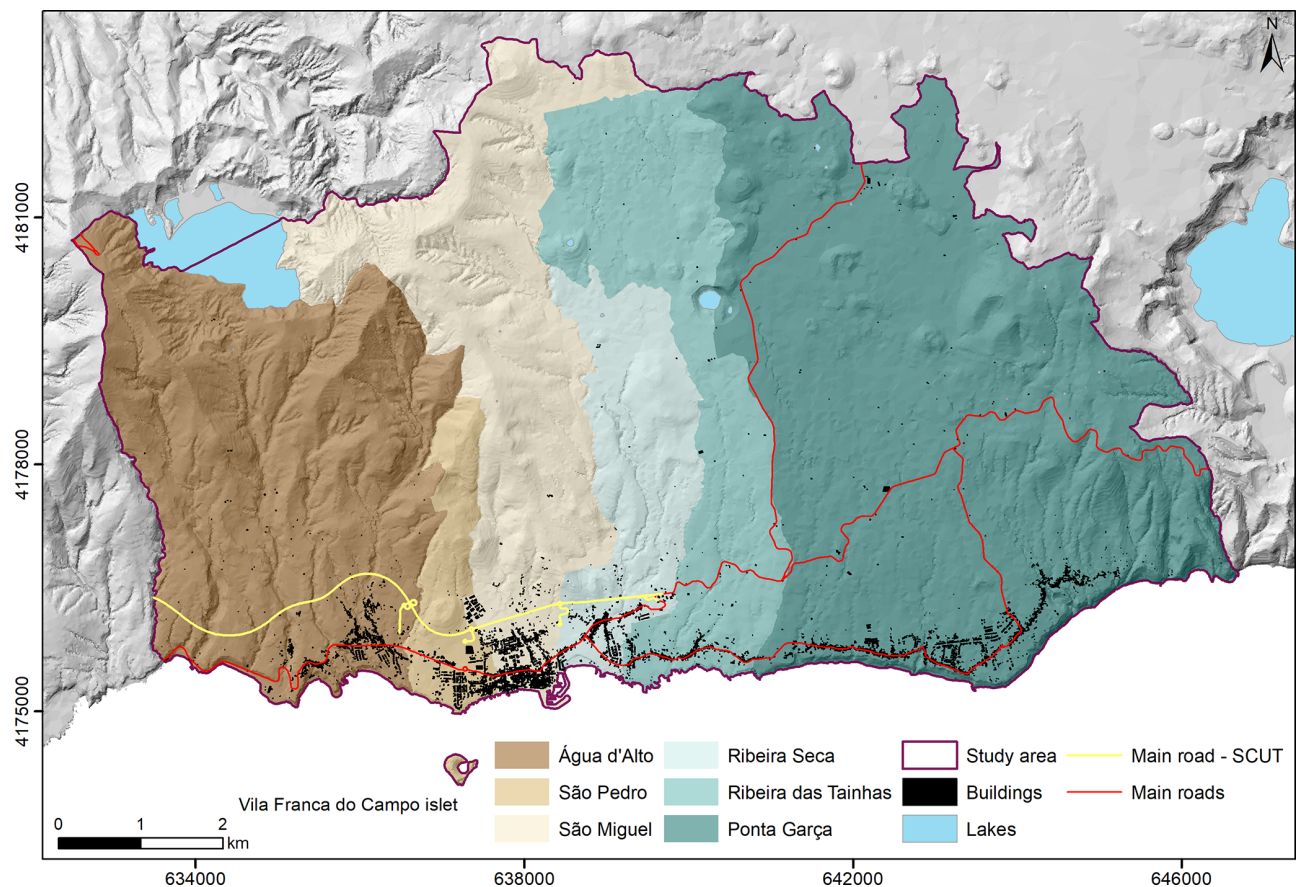

Figure 2. Location of Vila Franca do Campo municipality (the study area) on São Miguel Island showing the six parishes, buildings, infrastructure and main roads. UTM coordinates, zone 26S, datum WGS 84.

between summer (May to September) and winter periods (October to April). In the troposphere (and lower levels of the stratosphere, i.e. up to $17000 \mathrm{~m}$ altitude), the most frequent directions in the summer period are between west and north-west and between north and north-west, whereas in the winter period the dominant trend is west to southwest-blowing winds. At higher altitudes (above $17000 \mathrm{~m}$ ), a strong eastern direction prevails during the summer period, while in the winter period a western direction dominates (Pimentel et al., 2006; Gaspar et al., 2015a). The most probable combinations of wind direction and intensity were chosen for different vertical heights according to the simulated column height. Wind input parameters are summarised in Table 1.

In total four tephra fallout scenarios were simulated: (1) VEI 4 sub-Plinian eruption during the summer period, (2) VEI 4 sub-Plinian eruption during the winter period, (3) VEI 5 Plinian eruption during the summer period and (4) VEI 5 Plinian eruption during the winter period.

\subsubsection{Pyroclastic density currents}

Simulations of PDCs were performed with the energy cone model (Malin and Sheridan, 1982), which provides a fast and conservative approach to assessing the maximum potential extent of these volcanic products (e.g. Alberico et al., 2002, 2008; Felpeto et al., 2007; Toyos et al., 2007). The maximum potential extent of a PDC is directly related to the VEI of the eruption and the topography around the vent. A higher VEI implies that the PDC can reach larger distances (Alberico et al., 2008).

Input parameters used in the simulations were collapseequivalent heights of 300 and $500 \mathrm{~m}$ (for VEI 4 sub-Plinian and VEI 5 Plinian scenarios, respectively) and a constant collapse-equivalent angle of $6^{\circ}$, in agreement with previous studies (e.g. Alberico et al., 2002, 2008, 2011; Cole et al., 2008). Both simulations were preformed assuming a source area equal to the floor of the caldera, where each $50 \mathrm{~m}$ cell had an equal probability of generating PDCs.

\subsection{Exposed elements}

The vulnerability of buildings and infrastructure to different volcanic products depends on the type of construction materials, the quality of the workmanship, the age and maintenance level, their shape, and orientation (Pomonis et al., 1999) but also on the loss of benefits from the activity for which they are intended. Thus, in the particular case of explosive eruptions, we considered the vulnerability of buildings to tephra fallout and PDCs. In this study, we do not intend to assess the damage to the buildings but instead the loss of functionality.

To identify the exposed elements, a detailed inventory of all buildings and infrastructure related to the tourism sector in Vila Franca do Campo municipality was carried out during the summer of 2017. This followed a similar approach to the studies carried out by Pomonis et al. (1999) in Furnas parish and Gomes et al. (2006) in the parishes located on the 
Table 1. Input parameters used for the simulations of VEI 4 sub-Plinian and VEI 5 Plinian eruptions.

\begin{tabular}{llrl}
\hline \multicolumn{2}{l}{ Eruptive source parameters } & \multicolumn{2}{l}{ References } \\
\hline VEI 4 sub-Plinian & Bulk volume $\left(\mathrm{km}^{3}\right)$ & $\begin{array}{l}1 \\
\text { Column height }(\mathrm{m})\end{array}$ & $\begin{array}{l}\text { Booth et al. (1978) } \\
\text { Carey and Sparks (1986) }\end{array}$ \\
\hline VEI 5 Plinian & Bulk volume $\left(\mathrm{km}^{3}\right)$ & 3.2 & Booth et al. (1978) \\
& Column height $(\mathrm{m})$ & 27000 & Bursik et al. (1992) \\
\hline Grain size & Mean diameter $(\mathrm{Md} \Phi)$ & 0 & Cole et al. (1995) \\
& Standard deviation $(\sigma \Phi)$ & 2 & Cole et al. (1995) \\
& Minimum $(\Phi)$ & 4 & Walker and Croasdale (1971) \\
& Maximum $(\Phi)$ & -4 & Walker and Croasdale (1971) \\
\hline Clast density $\left(\mathrm{kg} \mathrm{m}^{-3}\right)$ & Large $(\Phi<1)$ & 800 & Wilson and Huang (1979) \\
& Medium $(1 \leq \Phi \leq 3)$ & 1200 & Wilson and Huang (1979) \\
& Small $(\Phi>3)$ & 2300 & Wilson and Huang (1979) \\
\hline
\end{tabular}

\begin{tabular}{|c|c|c|c|c|c|c|}
\hline Wind conditions & & & & & & \\
\hline \multicolumn{7}{|l|}{ VEI 4 sub-Plinian } \\
\hline \multirow[t]{3}{*}{ Summer period } & Altitude (m) & 1500 & 6125 & 10750 & 15375 & 20000 \\
\hline & Direction $\left(^{\circ}\right)$ & 270 & 315 & 315 & 270 & 90 \\
\hline & Intensity $\left(\mathrm{m} \mathrm{s}^{-1}\right)$ & 8 & 17 & 20 & 8 & 6 \\
\hline \multirow[t]{3}{*}{ Winter period } & Altitude (m) & 1500 & 6125 & 10750 & 15375 & 20000 \\
\hline & Direction $\left({ }^{\circ}\right)$ & 270 & 270 & 270 & 270 & 270 \\
\hline & Intensity $\left(\mathrm{m} \mathrm{s}^{-1}\right)$ & 17 & 20 & 20 & 17 & 11 \\
\hline \multicolumn{7}{|l|}{ VEI 5 Plinian } \\
\hline \multirow[t]{3}{*}{ Summer period } & Altitude (m) & 1500 & 8125 & 14750 & 21375 & 28000 \\
\hline & Direction $\left({ }^{\circ}\right)$ & 270 & 315 & 270 & 90 & 90 \\
\hline & Intensity $\left(\mathrm{m} \mathrm{s}^{-1}\right)$ & 8 & 17 & 18 & 8 & 11 \\
\hline \multirow[t]{3}{*}{ Winter period } & Altitude (m) & 1500 & 8125 & 14750 & 21375 & 28000 \\
\hline & Direction $\left({ }^{\circ}\right)$ & 270 & 270 & 270 & 270 & 270 \\
\hline & Intensity $\left(\mathrm{m} \mathrm{s}^{-1}\right)$ & 17 & 20 & 20 & 10 & 17 \\
\hline
\end{tabular}

flanks of Sete Cidades volcano (São Miguel Island) and by Cabral (2015) in Santa Catarina municipality (Fogo Island, Cape Verde).

The inventory included accommodation (hotels, guest houses, rural tourism, local accommodations), restaurants (ice cream shops, pastry shops, cafes, pubs), tourism animation and activities (travel agencies, rent-a-cars, nautical and terrestrial activities, souvenirs shops), and culture (churches and places of cult, museums, libraries, theatres, marketplaces, cultural centres).

Although this study does not intend to assess building damage but rather its loss of functionality, the inventory was based on a classification method developed by the Centre for Volcanology and Geological Hazards Assessment (CVARG) of the University of the Azores, now the Research Institute for Volcanology and Risk Assessment (IVAR), to study building vulnerability to different geological hazards in the Azores. This method classifies buildings according to use, number of floors, type of materials used in the construction, roof inclination, type of windows, etc. Details on the classification method can be found in Gaspar et al. (2004) and Gomes et al. (2006). The exposed elements (i.e. buildings and infrastructure associated with tourism in Vila Franca do Campo) were mapped in detail in a GIS.

The inventoried elements were then combined with the maps resulting from the different numerical simulations of tephra fallout and PDCs. This allowed us to identify which buildings and infrastructure would be affected by a certain thickness of tephra as well as those located within the maximum potential extent of PDCs.

\subsection{Economic value of tourism}

The methodology used to assess the impact of future explosive eruptions of Fogo volcano on the tourism economy consists of evaluating the benefits generated by the accommodation units of Vila Franca do Campo municipality. With that aim, we determined the current loss of revenue over a period of 30 years for different eruptive scenarios and discount rates 
and considered the evolution of the occupancy rate of the accommodation capacity. This study follows the approach proposed by Vianna et al. (2012) that quantifies the value of a tourism industry based on shark diving in the Republic of Palau (Pacific Ocean), one of the main activities that contributes to the country's economy.

In the present case and following the building inventory, we calculated the annual income of 46 accommodation units by estimating the average price per night of each unit. To calculate this value, we considered the price of one night in March 2018 (low season) and the cost of one night in August 2018 (high season). Some of the costs were obtained directly, provided by a representative of the accommodation unit, while others were obtained indirectly through online booking and shopping platforms as well as through the establishments' own websites. In specific cases, when it was not possible to obtain this information, an average cost was calculated considering the type of accommodation.

The annual revenue was obtained by multiplying the average cost per night by $365 \mathrm{~d}$ for the cases where the rent corresponds to the entire accommodation building. For the cases where the rent corresponds to only one room (e.g. hotels, apartments or chalets), the average cost of one room was multiplied by $365 \mathrm{~d}$ and by the number of rooms of the accommodation unit. The total annual revenue of the tourism sector in Vila Franca do Campo at 2018 values was obtained by adding up the annual revenues of each of the 46 accommodation units. However, this total revenue presupposes an occupancy rate of $100 \%$ of the existing accommodation capacity. To consider a more realistic situation, the total annual revenue was multiplied by a factor of 0.5 and 0.65 to assume an occupancy rate of $50 \%$ and $65 \%$, respectively. This creates two alternative scenarios for the existing accommodation capacity (explained later on).

To calculate the economic loss in Vila Franca do Campo municipality due to future explosive eruptions, we considered three economic scenarios resulting from the numerical simulations: (1) destruction of accommodation buildings affected by $\geq 20 \mathrm{~cm}$ of tephra fallout from a VEI 4 sub-Plinian eruption during the summer period, (2) destruction of accommodation buildings located within the maximum potential extent of PDCs generated by a VEI 4 sub-Plinian eruption and (3) destruction of accommodation buildings located within the maximum potential extent of PDCs generated by a VEI 5 Plinian eruption.

Economic scenarios 1 and 2 (tephra fallout and PDCs, respectively) from a VEI 4 sub-Plinian eruption are more conservative and realistic in case of a future explosive eruption of Fogo volcano. Regarding tephra fallout, the summer period was chosen as it is the high season of touristic activity but also because it corresponds to the wind conditions that would affect a larger portion of the study area. Economic scenario 3 (PDCs from a VEI 5 Plinian eruption) is not the most likely but represents the worst case possible, assuming near-total destruction of the study area. The annual revenue of the accommodation units was calculated for these three scenarios.

The next step was to calculate the loss present value (LPV) for each of the economic scenarios. The LPV corresponds to the value lost (in euros) after a certain period of time, discounted to the initial period (2018), which corresponds to year $0\left(t_{0}\right)$, following the expression

$\mathrm{LPV}=\sum_{t_{0}}^{t_{i}} \frac{R_{t}}{(1+r)^{t}}$,

where $t$ is the year ( 0 to $i$ ); $R_{t}$ is the revenue of the accommodation units in year $t$, taking into account the occupancy rate; and $r$ is the discount rate.

The occupancy rate (ro) is the percentage of occupied units or rooms in a certain area during a specific period. The discount rate $(r)$ is an intertemporal preference rate that allows the conversion of future values into present values and accounts for the notion that a given monetary amount does not have the same value in the present and in the future. A discount rate equal to 0 is used when it is intended to give the same weight to future and present values in a long-term analysis. This rate is considered a critical element in cost-benefit analysis when costs and benefits accrue over a number of years. The social discount rate is used when examining costs of benefits accruing by society, and its value has been calculated by researchers or sometimes externally proposed by government agencies for purposes of project or even environmental loss evaluation (Courard-Hauri et al., 2020). Evans and Sezer (2004) propose discount rates for six major countries ranging between $3.5 \%$ (France) and $5 \%$ (Japan). Evans and Sezer (2005) argue that social discount rates in European Union member countries mostly lie in the range of $3 \%$ to $5.5 \%$, while Florio and Sirtori (2013) estimate a set of values ranging from $1.13 \%$ (Italy) to $6.52 \%$ (Estonia). For Portugal, Florio (2006) estimates a $4 \%$ discount rate, and Florio and Sirtori (2013) suggest $1.67 \%$. According to the Official Journal of the European Union (2006), in 2006 the discount rate in Portugal should vary between $3.70 \%$ and $4.62 \%$ (January to December, respectively).

In this study, we considered a period of 30 years for the analysis, following the example of the eruption of Soufrière Hills volcano (Montserrat, Lesser Antilles) that started in 1995. This eruption also occurred on an island and produced tephra fallout, PDCs and lahars, with devastating consequences that last until today, even after more than 2 decades. Currently Montserrat's tourism industry is still in a recovery phase (Pacheco and Lewis-Cameron, 2010). The LPV was calculated for each of the chosen economic scenarios, considering two occupancy rates of the existing accommodation capacity: one more conservative, with an occupancy rate of $50 \%$ and discount rates of $0 \%, 2 \%$ and $4 \%$, and another less conservative, considering that Azores tourism shows a growing tendency, with an occupancy rate of $65 \%$ and the same discount rates $(0 \%, 2 \%$ and $4 \%)$. Discount rates between $2 \%$ and $4 \%$ lie in the range of values estimated for 
Portugal and mentioned above. Moreover, the choice of two discount rates is also justified by the factors related to uncertainty. Moreover, the use of a higher (lower) discount rate can be seen to some extent as a way of giving less (more) weight to future and therefore uncertain (or risky) monetary flows associated with the touristic activity. Finally, the impact of discounting can be assessed through comparison with a zero-discount baseline.

\section{Numerical-simulation results}

\subsection{Tephra fallout from VEI 4 sub-Plinian eruption}

The VEI 4 sub-Plinian simulation for the summer period (Fig. 3a) shows that Vila Franca do Campo, located southeast of Fogo caldera, is the most affected municipality of São Miguel, with $>3 \mathrm{~m}$ of tephra fall deposited in the caldera and immediately east-south-east of the vent. Almost all the municipality is affected by tephra deposition up to $2 \mathrm{~m}$ thick. The predominant winds from the west-north-west also lead to the deposition of tephra on the western half of Povoação municipality (between $50 \mathrm{~cm}$ and $1 \mathrm{~mm}$, from west to east) and on the southern part of Ribeira Grande municipality (up to $3 \mathrm{~m}$ close to the caldera).

For the winter period (Fig. 3b), the prevailing winds from the west and the higher wind intensities promote the deposition of tephra on the eastern part of the island. Although Vila Franca do Campo is located on the south-east flank of the volcano, the strong westerly winds cause most of the tephra to be deposited on the northern sector of the municipality, with $>3 \mathrm{~m}$ immediately to the east of the caldera. However, in this scenario the entire Povoação municipality is affected by tephra fall that can reach maximum thicknesses of 1 to $2 \mathrm{~m}$ in much of its area. Ribeira Grande and Nordeste municipalities are also affected in their southern sectors, although with smaller thicknesses ( $1 \mathrm{~m}$ to $1 \mathrm{~mm}$, from south to north).

\subsection{Tephra fallout from VEI 5 Plinian eruption}

The VEI 5 Plinian simulations show the same dispersal patterns of the VEI 4 sub-Plinian simulations described above but with greater extents. For the summer period (Fig. 4a), Vila Franca do Campo municipality is the most affected, with $>3 \mathrm{~m}$ of tephra deposited on its northern part, eastsouth-east of the caldera. Much of the municipality is affected by tephra deposition between 1 and $3 \mathrm{~m}$ thick. The neighbouring Povoação municipality is affected by tephra fall up to $1 \mathrm{~m}$ thick, particularly on the western side. The southern part of Ribeira Grande municipality is also affected by thicknesses of $>3 \mathrm{~m}$ of tephra close to the caldera.

For the winter period (Fig. 4b), the predominant stronger winds blowing from the west lead to the deposition of tephra on the eastern part of São Miguel. Vila Franca do Campo is affected by thick tephra deposition $(>3 \mathrm{~m})$ in the northern sector of the municipality. Given the higher intensities of the wind, tephra thicknesses of 1 to $3 \mathrm{~m}$ are deposited on much of Povoação municipality, reaching $>3 \mathrm{~m}$ in the western part. Ribeira Grande and Nordeste municipalities are also affected in their southern sectors, with thicknesses of $2 \mathrm{~m}$ to $1 \mathrm{~mm}$, from south to north.

\subsection{Pyroclastic density currents}

The simulations of PDCs for the VEI 4 sub-Plinian and VEI 5 Plinian eruptions (Fig. 5) show the maximum potential extent of these volcanic products generated from within Fogo caldera. In both cases, PDCs are not contained inside the caldera and flow down the flanks of the volcano. The entire central part of São Miguel may be affected by PDCs, which reach the sea on the north and south coasts. As expected, the VEI 4 and VEI 5 simulations differ in the maximum potential extent that the PDCs can achieve. The VEI 4 simulation (dotted blue line in Fig. 5) shows that the western half of Vila Franca do Campo, most of Lagoa and the central part of Ribeira Grande municipalities are affected by PDCs, which can reach maximum distances of $9 \mathrm{~km}$ from the caldera. In the case of the VEI 5 simulation (dashed red line in Fig. 5), more than two-thirds of Vila Franca do Campo, all of Lagoa and the central part of Ribeira Grande municipalities are affected by PDCs that can reach maximum distances of $11 \mathrm{~km}$ from the source.

\section{Exposed elements at risk}

The inventory and characterisation of buildings related to tourism in Vila Franca do Campo municipality (140 in total) revealed that 46 correspond to accommodation units $(33 \%)$, 51 correspond to restaurants $(36 \%), 29$ are destined to culture or cultural activities ( $21 \%$ ), and 14 buildings are related to tourism animation and activities (10\%) (Fig. 6). Infrastructure such as the marina, the fishing port and the water park were also considered in the analysis.

The identification of the elements at risk was attained by overlapping the mapped exposed elements (buildings and infrastructure) with the results of the simulations (Figs. 7 to 9). Regarding tephra fallout scenarios, it is important to distinguish the type of destruction that the buildings can suffer depending on the tephra thicknesses. When a building (represented by a polygon) was overlapped by more than one thickness class we considered the most conservative option by choosing the class with the higher thickness. The impact on the buildings was assessed according to the expected type of destruction following critical thickness thresholds.

Buildings affected by $1 \mathrm{~mm}$ to $20 \mathrm{~cm}$ of tephra and subject to constant and careful cleaning of the roof are usually not damaged or may suffer only minor damage. For the summer period (Figs. 7a and 8a), 62.1\% and 61.4\% (VEI 4 sub-Plinian and VEI 5 Plinian scenarios, respectively) of all buildings related to tourism are likely to suffer thicknesses 

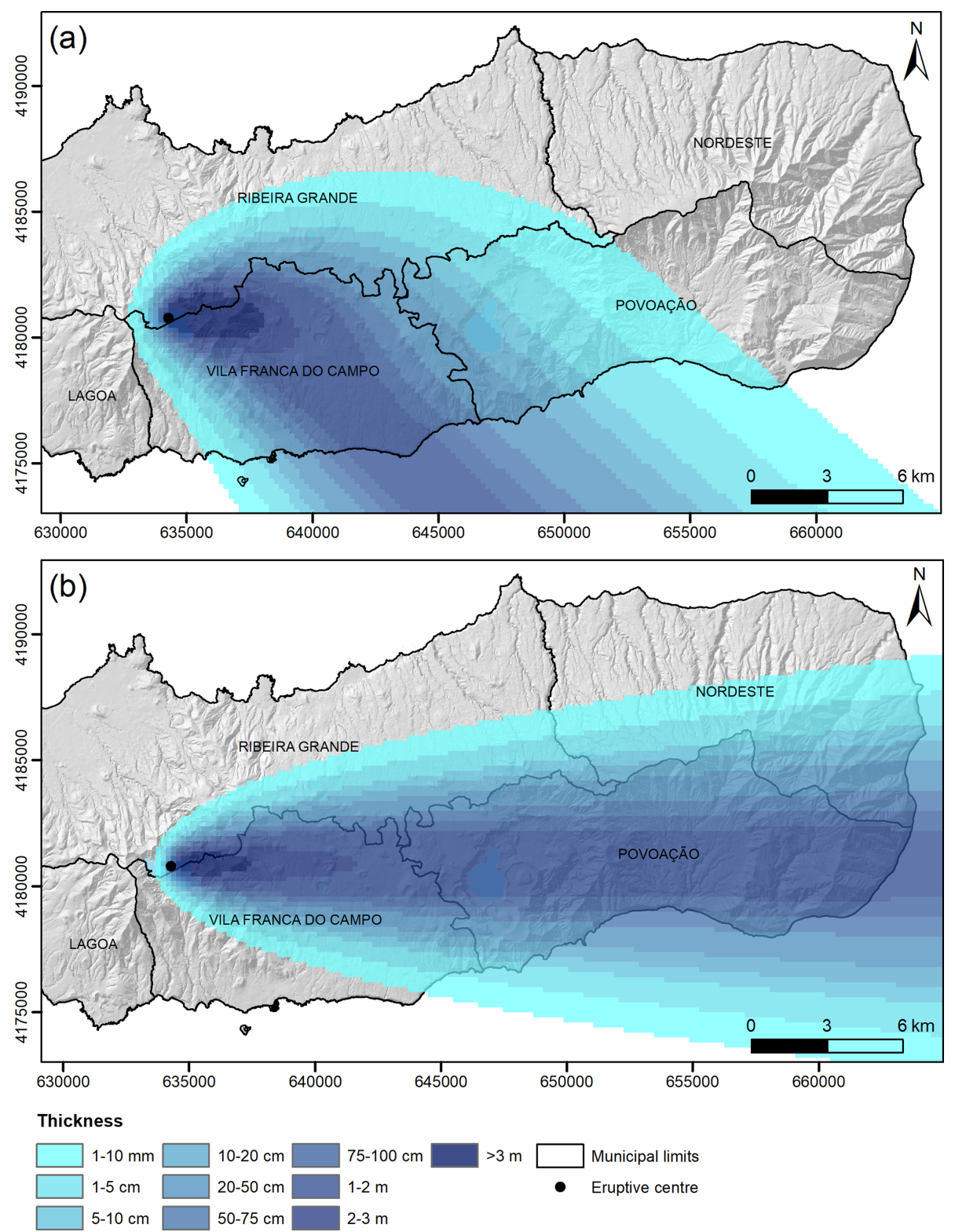

Figure 3. (a) Tephra fallout deposition from a VEI 4 sub-Plinian eruption of Fogo volcano, considering the dominant winds for the summer period. (b) Tephra fallout deposition from a VEI 4 sub-Plinian eruption of Fogo volcano, considering the dominant winds for the winter period. UTM coordinates, zone 26S, datum WGS 84.

of up to $20 \mathrm{~cm}$. On the other hand, for the winter period (Figs. 7b and 8b) buildings in Vila Franca do Campo municipality will only be covered by a maximum of $5 \mathrm{~cm}$ of tephra. The affected buildings are located in Ponta Garça, the easternmost parish, and correspond to $5 \%$ and $15 \%$ (VEI 4 sub-Plinian and VEI 5 Plinian scenarios, respectively) of all touristic buildings (see Table 2).

Buildings covered by $\geq 20 \mathrm{~cm}$ of tephra can suffer significant damage, such as roof collapse (Pomonis et al., 1999). For both summer scenarios (Figs. 7a and 8a), approximately $31 \%$ of the buildings are in these conditions. In more extreme cases, buildings affected by $\geq 1 \mathrm{~m}$ of tephra are likely to suffer total collapse (Blong, 1984; Spence et al., 2005). For this case, the percentage of affected buildings is higher in the VEI 5 Plinian scenario, with $19 \%$, whereas in the VEI 4 sub-Plinian scenario it is $9.3 \%$ (Table 2).

Concerning PDCs, it should be noted that the distinction between dense and dilute currents was not taken into account in this analysis, and therefore only total destruction was considered. The percentage of tourism-related buildings located within the maximum potential extent of PDCs (Fig. 9) from a VEI 4 sub-Plinian eruption is $87.1 \%$, whereas from a VEI 5 Plinian eruption it is $95 \%$. 

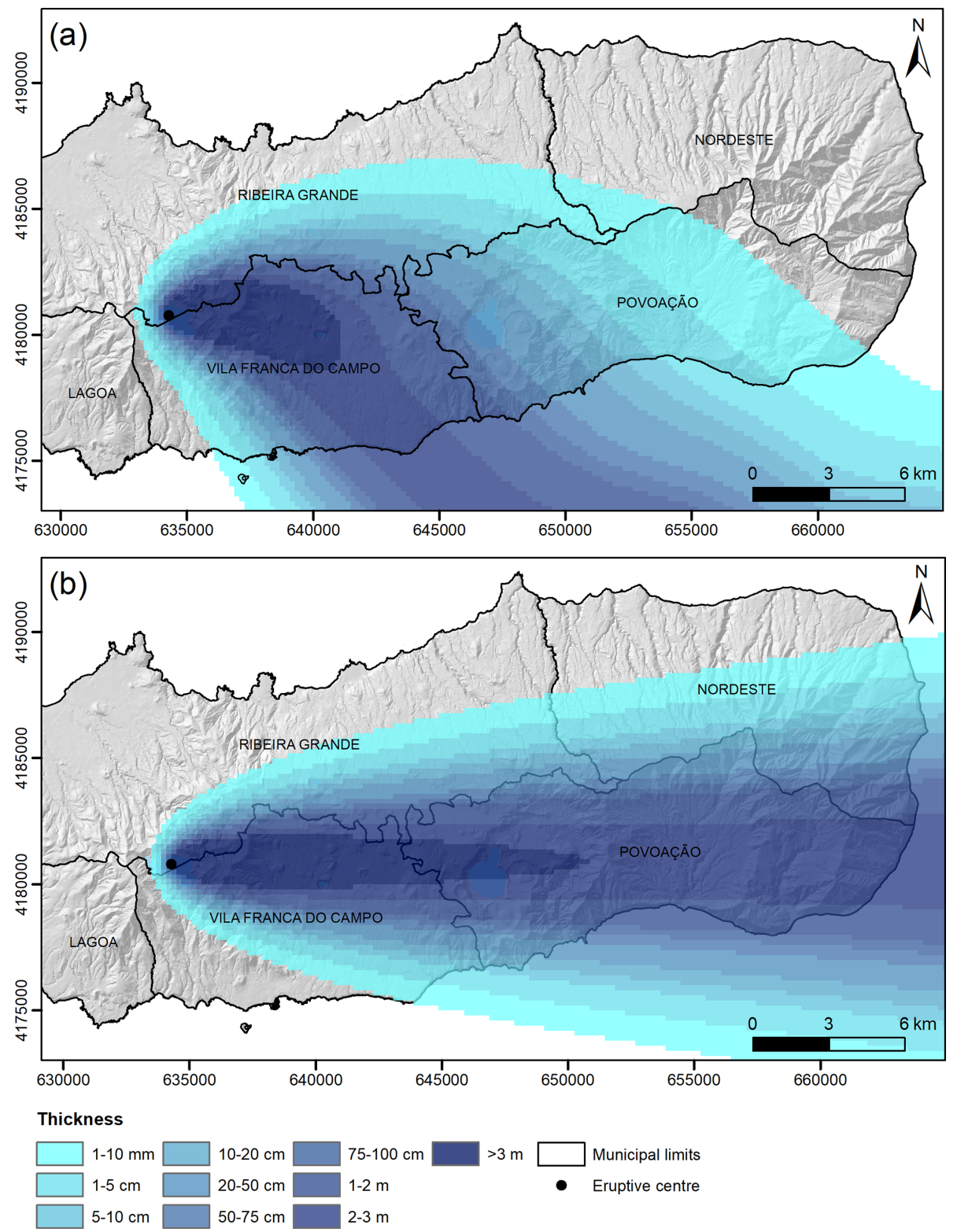

Figure 4. (a) Tephra fallout deposition from a VEI 5 Plinian eruption of Fogo volcano, considering the dominant winds for the summer period. (b) Tephra fallout deposition from a VEI 5 Plinian eruption of Fogo volcano, considering the dominant winds for the winter period. UTM coordinates, zone 26S, datum WGS 84.

Table 2. Percentage of buildings affected by tephra fallout from VEI 4 sub-Plinian and VEI 5 Plinian eruption scenarios in the summer and winter period.

\begin{tabular}{lllll|ll}
\hline \multirow{2}{*}{ Tephra thickness } & \multicolumn{3}{c}{ Summer period scenarios } & \multicolumn{2}{c}{ Winter period scenarios } \\
\cline { 2 - 6 } & Unaffected & $1 \mathrm{~mm}-20 \mathrm{~cm}$ & $20 \mathrm{~cm}-1 \mathrm{~m}$ & $>1 \mathrm{~m}$ & Unaffected & $1 \mathrm{~mm}-5 \mathrm{~cm}$ \\
\hline VEI 4 sub-Plinian & $7.1 \%$ & $62.1 \%$ & $21 \%$ & $9.3 \%$ & $95 \%$ & $5 \%$ \\
VEI 5 Plinian & $7.9 \%$ & $61.4 \%$ & $12 \%$ & $19 \%$ & $85 \%$ & $15 \%$ \\
\hline
\end{tabular}




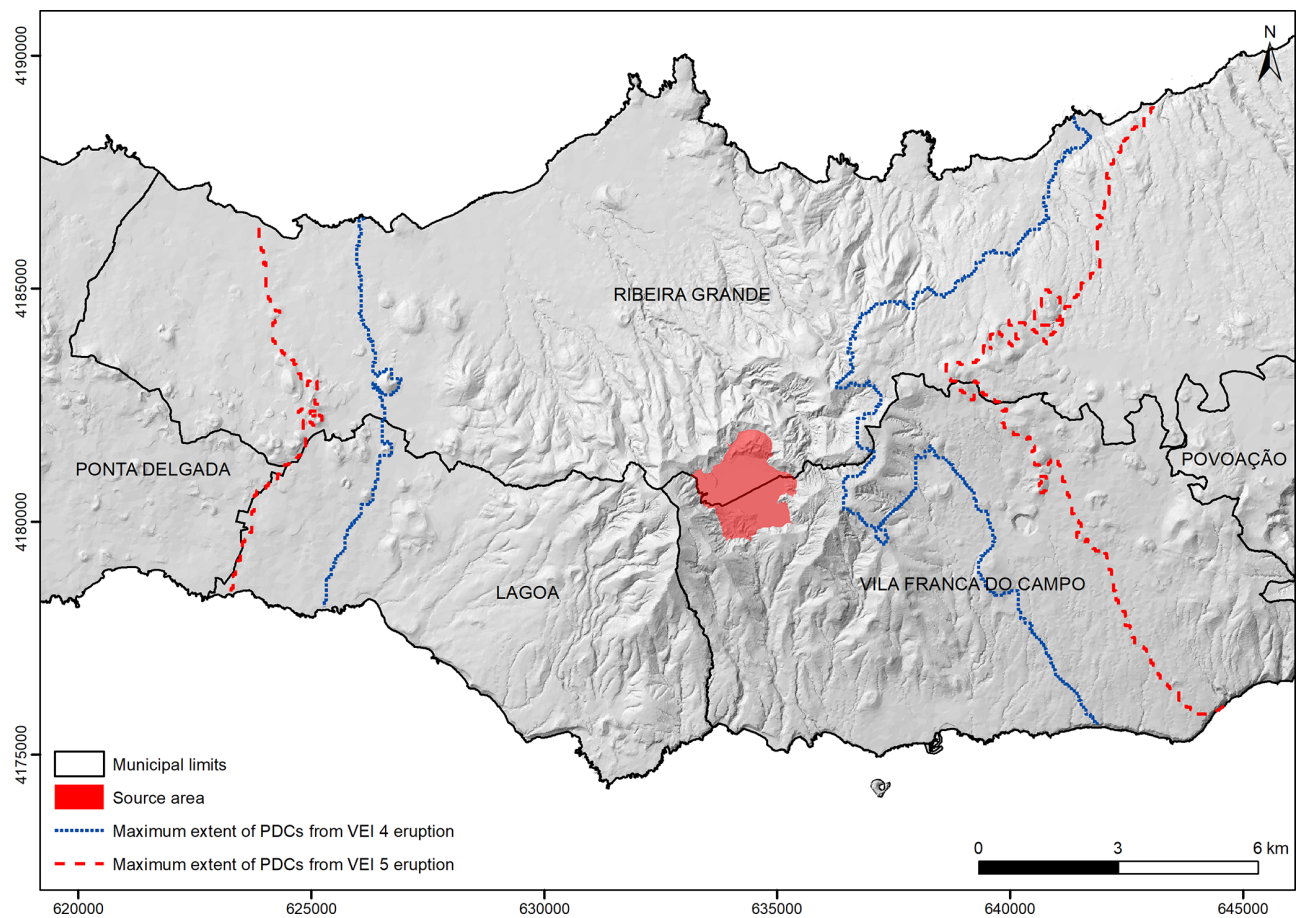

Figure 5. Maximum potential extent of PDCs from a VEI 4 sub-Plinian eruption (dotted blue line; collapse height of $300 \mathrm{~m}$ ) and from a VEI 5 Plinian eruption (dashed red line; collapse height of $500 \mathrm{~m}$ ) of Fogo volcano. UTM coordinates, zone $26 \mathrm{~S}$, datum WGS 84.

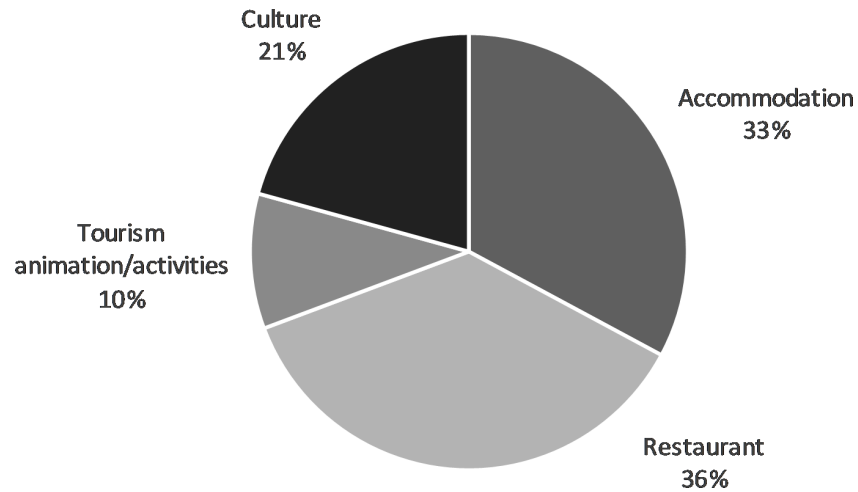

Figure 6. Percentage of buildings of each typology located in Vila Franca do Campo municipality.

In addition to buildings, infrastructure related to the tourism sector in Vila Franca do Campo municipality will suffer similar damage to the buildings when affected by tephra fallout (summer period) and PDCs. Like the other exposed elements, infrastructure will not be affected by tephra fallout in the winter period.

\section{Assessment of the economic impact on tourism}

The economic impact of future explosive eruptions of Fogo volcano on the tourism sector of Vila Franca do Campo mu- nicipality was calculated considering three economic scenarios. The number of accommodation buildings affected in each economic scenario is shown in Table 3.

The sum of the annual revenue of each accommodation unit resulted in an estimated total annual revenue of approximately EUR 9.5 million, assuming that the accommodation capacity was fully occupied. Combining the revenue data with the chosen occupancy and discount rates allowed the estimation of the LPV for a period of 30 years for each of the economic scenarios (Fig. 10). Table 4 summarises the occupancy rates $(r o)$, discount rates $(r)$ and LPV for the three economic scenarios considered.

The graphs of Fig. 10 show that in all scenarios the LPV is greater for higher occupancy rates and lower discount rates. For example, in economic scenario 3 (PDCs from a VEI 5 Plinian eruption) the LPV after 30 years is almost EUR 145 million when the applied occupancy rate is $65 \%$ and discount rate is $2 \%$. On the other hand, if an occupancy rate of $65 \%$ and a discount rate of $4 \%$ are considered, the loss is approximately EUR 113 million. The lowest value of the updated loss is EUR 87 million for an occupancy rate of $50 \%$ and a discount rate of $4 \%$. In terms of LPV per year, there is a decreasing trend over time in all scenarios. For economic scenario 3 and considering both discount rates, the loss value in year 0 does not reach EUR 5 million for occupancy rates of $50 \%$ and does not exceed EUR 6 million for a higher occupancy rate of $65 \%$ (Fig. 10c). However, over the years the LPV downward trend is more evident when a discount rate 

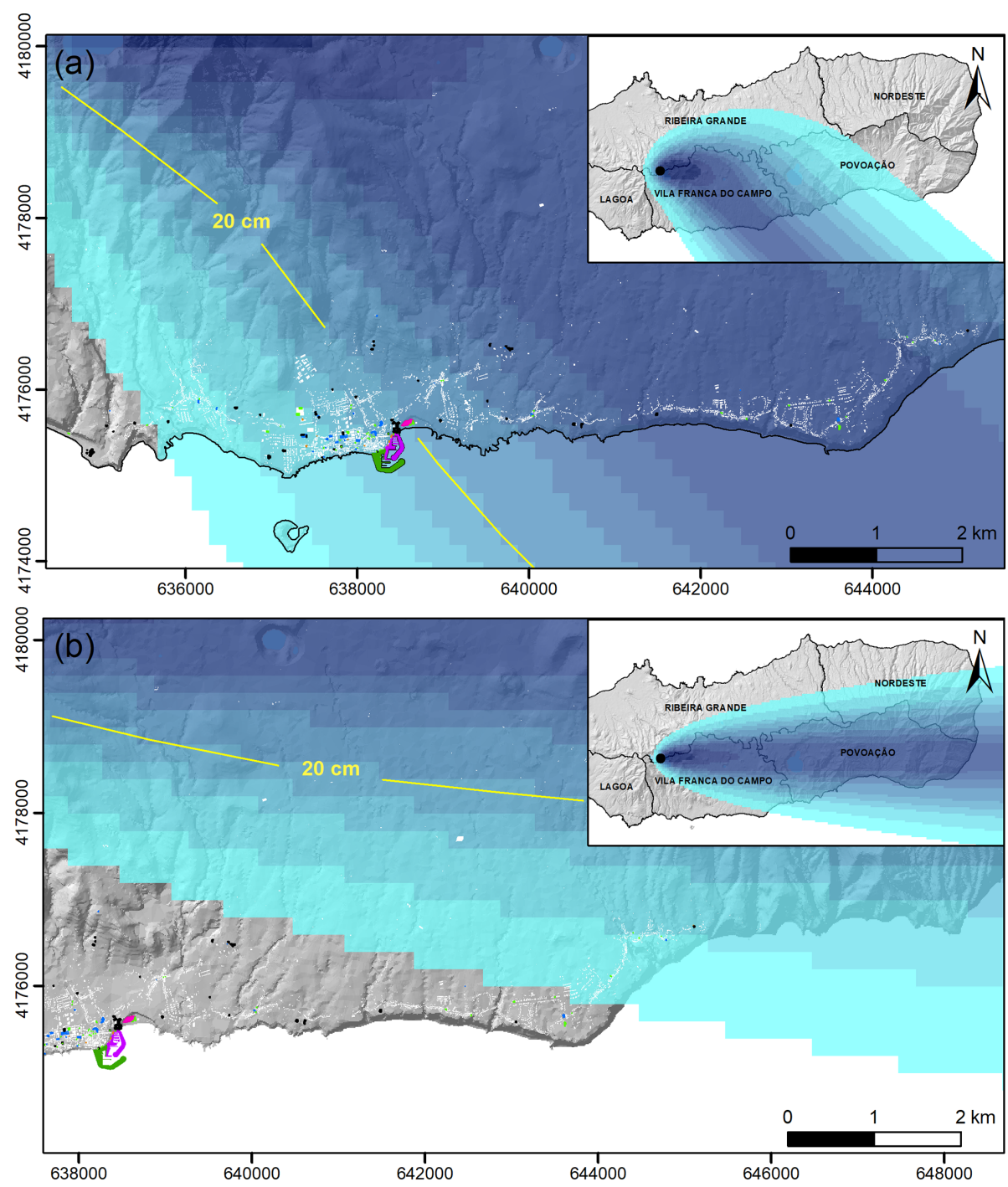

- Eruptive centre

Exposed elements at risk

Thickness

\begin{tabular}{|c|c|c|c|c|c|}
\hline $1-10 \mathrm{~mm}$ & $10-20 \mathrm{~cm}$ & $75-100 \mathrm{~cm}$ & $>3 \mathrm{~m}$ & Restaurant & Marina \\
\hline $1-5 \mathrm{~cm}$ & $20-50 \mathrm{~cm}$ & $1-2 \mathrm{~m}$ & & Tourism animation & Fishing port \\
\hline $5-10 \mathrm{~cm}$ & $50-75 \mathrm{~cm}$ & $2-3 \mathrm{~m}$ & & Culture & Other \\
\hline
\end{tabular}

Figure 7. (a) Spatial distribution of the elements at risk in Vila Franca do Campo municipality (colour polygons) affected by tephra fallout resulting from a VEI 4 sub-Plinian eruption at Fogo volcano, considering the dominant winds for the summer period. (b) Spatial distribution of the elements at risk in Vila Franca do Campo municipality affected by tephra fallout resulting from a VEI 4 sub-Plinian eruption of Fogo volcano, considering the dominant winds for the winter period. UTM coordinates, zone 26S, datum WGS 84.

Table 3. Number and percentage of buildings in each economic scenario.

\begin{tabular}{lrl}
\hline Economic scenario & $\begin{array}{r}\text { Number of accommo- } \\
\text { dation buildings }\end{array}$ & $\begin{array}{l}\text { Percentage of accommo- } \\
\text { dation buildings }\end{array}$ \\
\hline (1) Tephra fallout VEI 4 sub-Plinian & 17 & $36 \%$ \\
(2) PDCs VEI 4 sub-Plinian & 44 & $96 \%$ \\
(3) PDCs VEI 5 Plinian & 45 & $98 \%$ \\
\hline
\end{tabular}



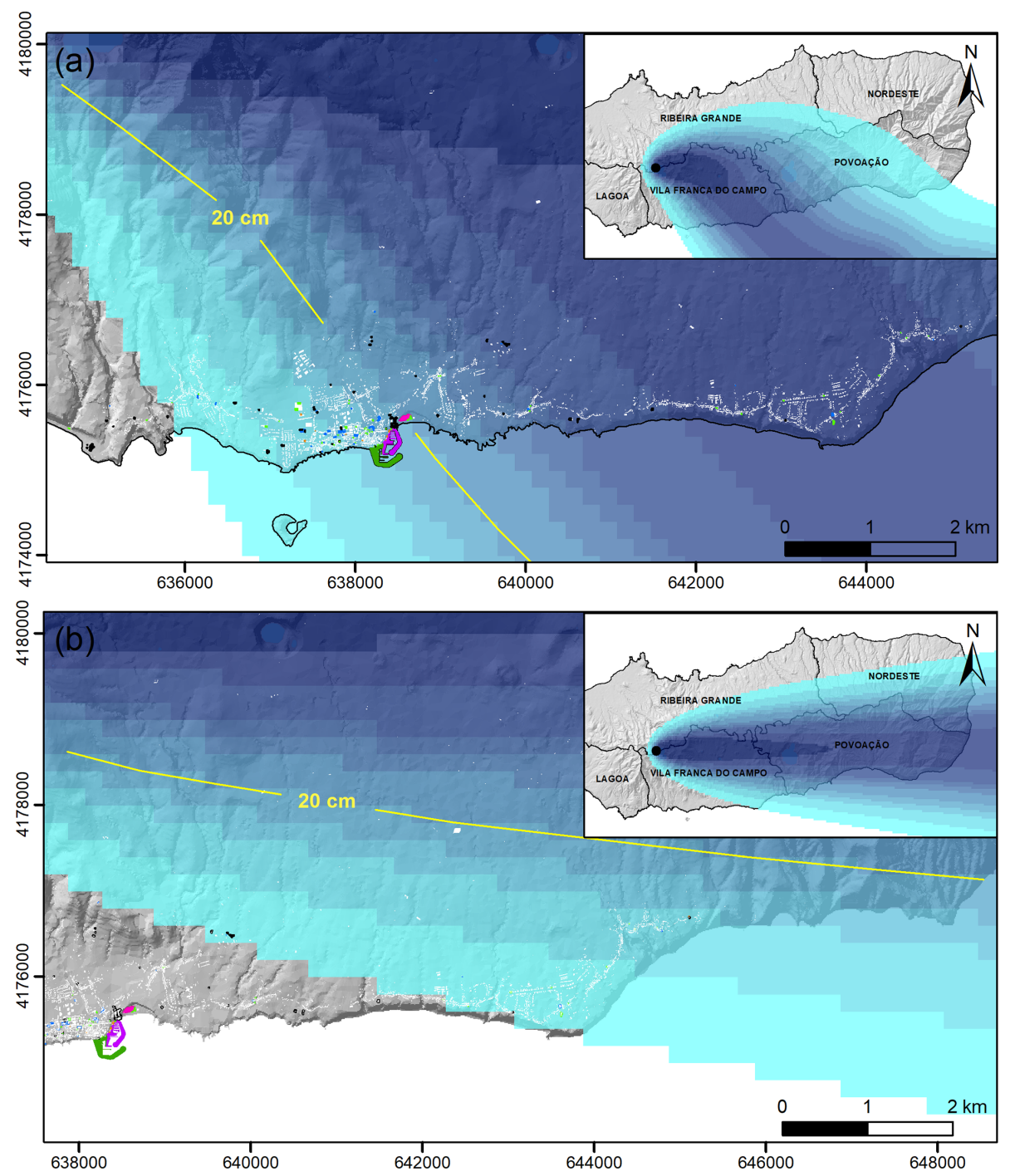

- Eruptive centre

Exposed elements at risk

Thickness

\begin{tabular}{|c|c|c|c|c|c|}
\hline Thickness & & & & Accommodation & Water park \\
\hline $1-10 \mathrm{~mm}$ & $10-20 \mathrm{~cm}$ & $75-100 \mathrm{~cm}$ & $>3 \mathrm{~m}$ & Restaurant & Marina \\
\hline $1-5 \mathrm{~cm}$ & $20-50 \mathrm{~cm}$ & $1-2 m$ & & Tourism animation & Fishing port \\
\hline $5-10 \mathrm{~cm}$ & $50-75 \mathrm{~cm}$ & $2-3 m$ & & Culture & Other \\
\hline
\end{tabular}

Figure 8. (a) Spatial distribution of the elements at risk in Vila Franca do Campo municipality (colour polygons) affected by tephra fallout resulting from a VEI 5 Plinian eruption of Fogo volcano, considering the dominant winds for the summer period. (b) Spatial distribution of the elements at risk in Vila Franca do Campo municipality affected by tephra fallout resulting from a VEI 5 Plinian eruption of Fogo volcano, considering the dominant winds for the winter period. UTM coordinates, zone $26 \mathrm{~S}$, datum WGS 84 .

is applied. For an occupancy rate of $65 \%$, the loss value in year 30 is EUR 1.9 million and EUR 3.4 million for discount rates of $4 \%$ and $2 \%$, respectively, while for an occupancy rate of $50 \%$, this value is approximately EUR 1.4 million and EUR 2.6 million, considering discount rates of $4 \%$ and $2 \%$, respectively.

The use of a discount rate equal to $0 \%$ means that society would attribute to a given monetary amount the same value in the future and in the present. Although this scenario is considered less realistic among economists and other agents, its use might be important to assess the impact of discounting. As expected, this exercise yields the highest LPV in all economic scenarios (Table 4). For instance, regarding economic scenario 3, LPV would amount to EUR 192 million at zero discounting and when a $65 \%$ occupancy is applied. This means that, in such a case, discounting at $2 \%$ and $4 \%$ rates reduces LPV by nearly EUR 47 million and EUR 79 million, respectively. Other similar calculations can be performed, 


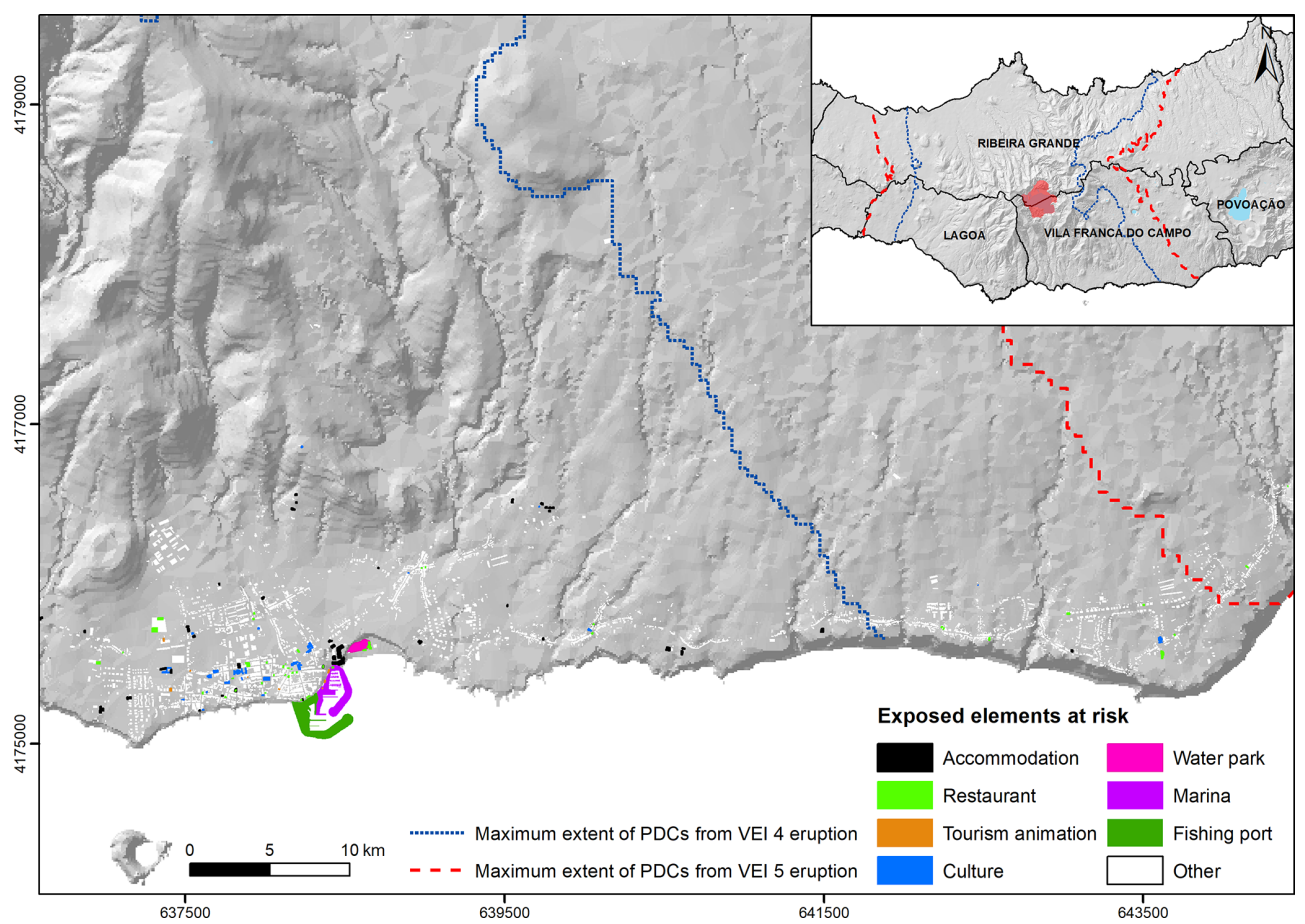

Figure 9. Spatial distribution of the elements at risk in Vila Franca do Campo municipality (colour polygons) affected by PDCs resulting from VEI 4 sub-Plinian (dotted blue line) and VEI 5 Plinian (dashed red line) eruptions of Fogo volcano. UTM coordinates, zone 26S, datum WGS 84.

Table 4. Loss present value after 30 years for economic scenario 1 (tephra fallout VEI 4 sub-Plinian eruption), economic scenario 2 (PDCs VEI 4 sub-Plinian eruption) and economic scenario 3 (PDCs VEI 5 Plinian eruption), considering discount rates of $0 \%, 2 \%$ and $4 \%$ and occupancy rates of $50 \%$ and $65 \%$.

\begin{tabular}{|c|c|c|c|}
\hline Economic scenario & Occupancy rate (ro) & Discount rate $(r)$ & LPV (euros) \\
\hline \multirow[t]{6}{*}{ (1) Tephra fallout VEI 4 sub-Plinian } & $50 \%$ & $0 \%$ & 18239551 \\
\hline & & $2 \%$ & 13765834 \\
\hline & & $4 \%$ & 10762532 \\
\hline & $65 \%$ & $0 \%$ & 23711416 \\
\hline & & $2 \%$ & 17895584 \\
\hline & & $4 \%$ & 13991291 \\
\hline \multirow[t]{6}{*}{ (2) PDCs VEI 4 sub-Plinian } & $50 \%$ & $0 \%$ & 144556924 \\
\hline & & $2 \%$ & 109100634 \\
\hline & & $4 \%$ & 85298067 \\
\hline & $65 \%$ & $0 \%$ & 187924002 \\
\hline & & $2 \%$ & 141830825 \\
\hline & & $4 \%$ & 110887487 \\
\hline \multirow[t]{6}{*}{ (3) PDCs VEI 5 Plinian } & $50 \%$ & $0 \%$ & 147725124 \\
\hline & & $2 \%$ & 111491752 \\
\hline & & $4 \%$ & 87167513 \\
\hline & $65 \%$ & $0 \%$ & 192042662 \\
\hline & & $2 \%$ & 144939278 \\
\hline & & $4 \%$ & 113317767 \\
\hline
\end{tabular}




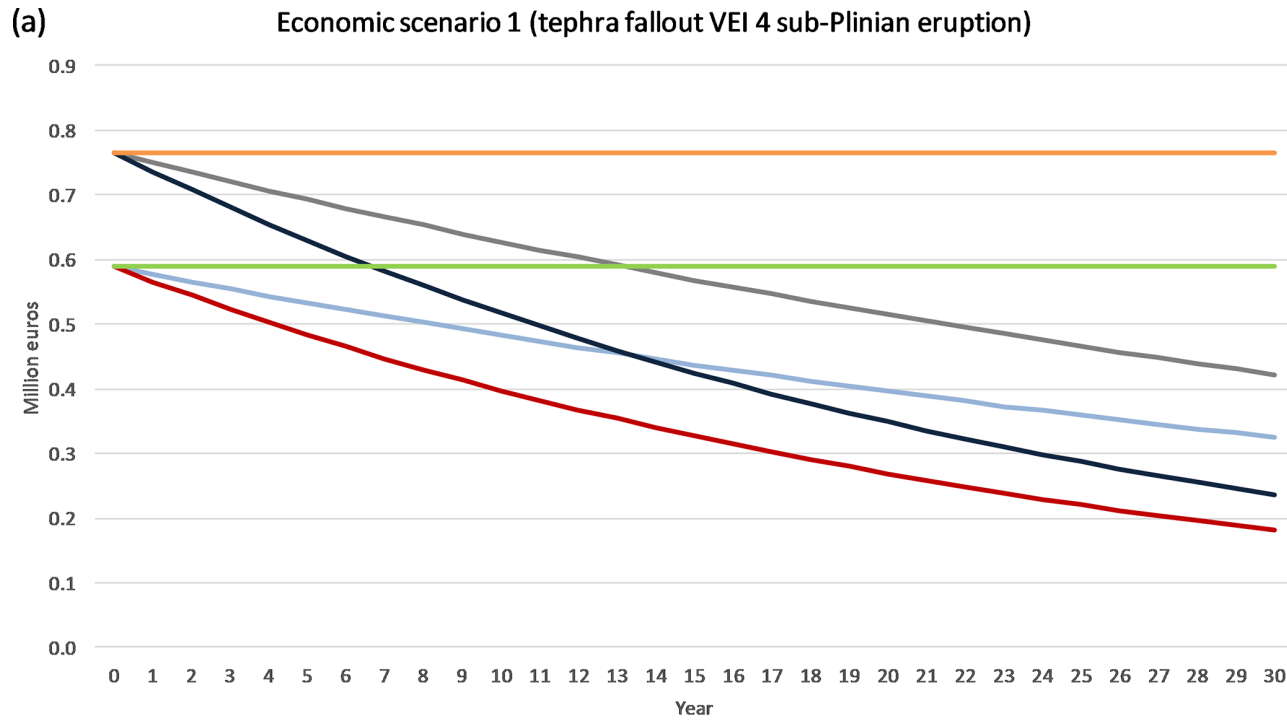

(b) Economic scenario 2 (PDCs VEl 4 sub-Plinian eruption)

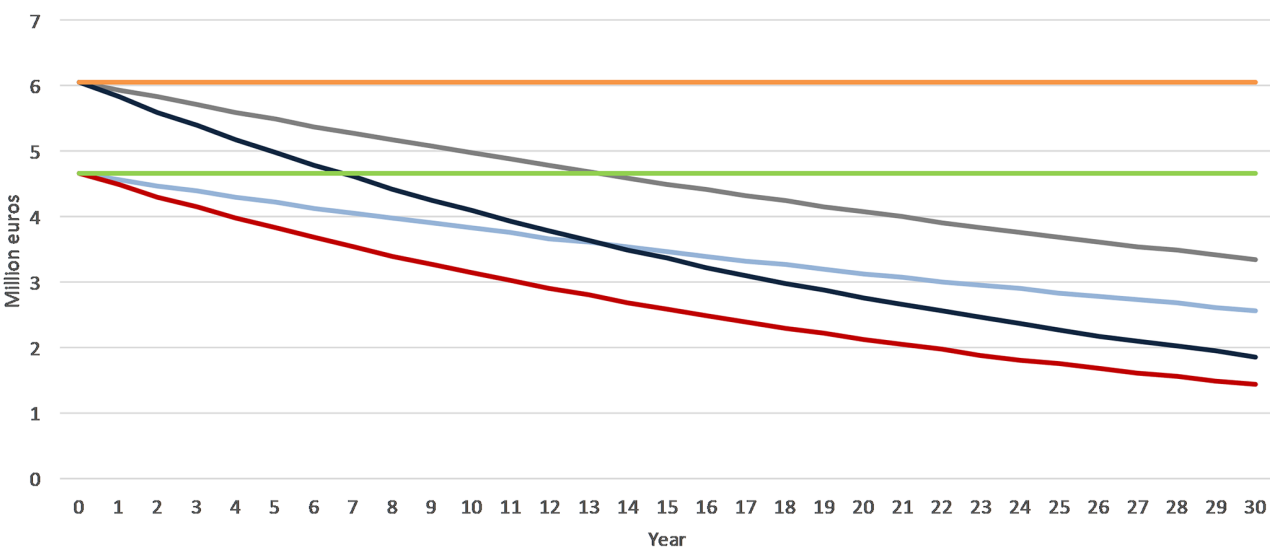

(c) Economic scenario 3 (PDCs VEI 5 Plinian eruption)

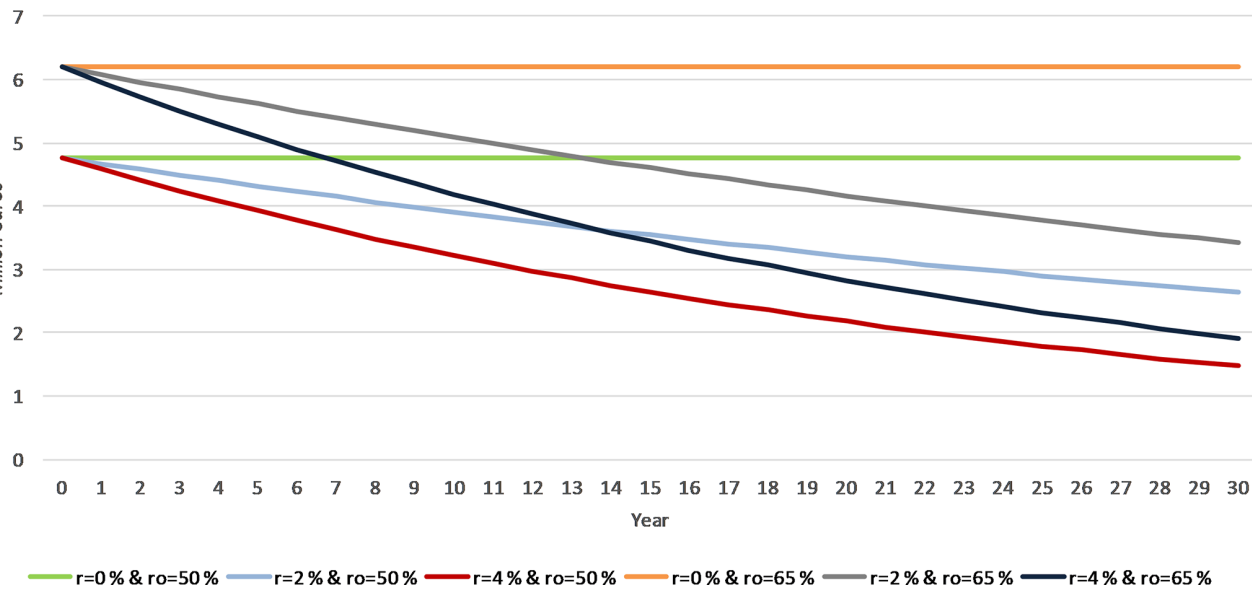

Figure 10. Loss present value after 30 years for (a) economic scenario 1 (tephra fallout VEI 4 sub-Plinian eruption), (b) economic scenario 2 (PDCs VEI 4 sub-Plinian eruption) and (c) economic scenario 3 (PDCs VEI 5 Plinian eruption), considering discount rates of $0 \%, 2 \%$ and $4 \%$ and occupancy rates of $50 \%$ and $65 \%$. 
namely for economic scenarios 1 and 2, based on the values included in Table 4.

\section{Discussion}

\subsection{Impact of tephra fallout and PDCs from Fogo volcano}

Fogo volcano is considered one of the most hazardous volcanoes in the Azores archipelago. Despite the low eruptive frequency of sub-Plinian and Plinian eruptions, with a recurrence interval of 833 years (Gaspar et al., 2015a), Fogo volcano produced the largest eruption in the Azores in the last 5000 years (Fogo A) and one of the most recent explosive eruptions of the archipelago (Fogo 1563) (Walker and Croasdale, 1971; Booth et al., 1978; Wallenstein, 1999). Even in non-eruptive periods, Fogo volcano is a hazardous landform with significant seismicity (Silva et al., 2015, 2020) and geothermal activity, manifested in fumarolic fields, thermal and cold $\mathrm{CO}_{2}$-rich springs, and diffuse degassing areas (Viveiros et al., 2015). Several unrest episodes have occurred in the last 20 years, with intense earthquake swarms lasting for several months and accompanied by ground deformation (inflation episodes), such as in May-September 2005 (Wallenstein et al., 2007; Silva et al., 2012). Due to its location, in the central part of São Miguel, a future explosive eruption of Fogo volcano will severely impact the parishes located on the flanks of the volcano but also others in more distal areas depending on wind conditions. Such an eruption will have significant long-term economic consequences for the island and even for the entire Azores archipelago. Next, we discuss the impact of tephra fallout and PDCs on São Miguel following the eruptive scenarios defined in this study.

The simulation of tephra fallout from a VEI 4 sub-Plinian eruption (most probable scenario) during the summer period, shows that the prevailing winds blowing from the west-northwest promote the deposition of tephra within the caldera and to the east-south-east of the vent, making Vila Franca do Campo municipality the most affected, with tephra deposition up to $2 \mathrm{~m}$ thick. For an eruption occurring during the winter period, the predominant winds blowing from the west and the higher wind intensities lead to the deposition of tephra on the eastern part of the island. Validation of the simulation results can be made by comparison with the geological record, namely with the deposit of the Fogo 1563 eruption, which has a well-defined dispersal axis towards the east (see the isopach map of the Fogo 1563 deposit in Fig. 20 of Walker and Croasdale, 1971). Regarding tephra fallout from a VEI 5 Plinian eruption (worst-case scenario), the simulation results show the same dispersion patterns as the VEI 4 sub-Plinian eruption scenario for summer and winter conditions, though with thicker tephra deposition due to the larger volume of ejected material.
The impact of tephra fallout on buildings and infrastructure will depend on the thickness of accumulated tephra, which is translated as static load. In localities affected by the accumulation of $20 \mathrm{~cm}$ or more of tephra, such as those in the central and eastern parts of Vila Franca do Campo, buildings would suffer significant damage. While in localities where the $1 \mathrm{~m}$ threshold is exceeded, such as Ponta Garça in the summer period, buildings would likely suffer total collapse, including constructions reinforced with concrete (Blong, 1984; Spence et al., 2005). However, if tephra is wet these critical thickness thresholds are substantially reduced (Spence et al., 2005). This possibility should not be overlooked given the rainy Azorean climate (Hernández et al., 2016).

Other elements such as the ground transportation network would also be affected by tephra fallout. As the main roads of Vila Franca do Campo are located in the southern part of the municipality, they are mostly vulnerable to the accumulation of tephra fall deposits during the summer period. Marine transportation can also be affected by tephra fallout as ports and marinas become inoperable. Particularly during the summer period, marine operations along the south coast of São Miguel would be severely affected, and important fishing ports, such as Vila Franca do Campo, would be brought to a halt.

The simulations of PDCs for VEI 4 sub-Plinian and VEI 5 Plinian eruptions show that these currents are not contained inside the caldera but are able to overcome the caldera walls and flow down the flanks of the volcano. The eruption of such volcanic products would affect the entire central part of São Miguel, reaching the sea on the north and south coasts of the island. The maximum potential extent of the PDCs is of the order of 9 and $11 \mathrm{~km}$ from the caldera for the VEI 4 and VEI 5 scenarios, respectively. It should be noted that in the case of a real event, the progression of PDCs is strongly controlled by topography and channelled through valleys and depressions along the flanks of the volcano. Validation of these simulations can be done by comparison with the geological record of PDC deposits. Fogo A ignimbrites were emplaced quasi-radially outward from the caldera, within narrow palaeo-valleys on the southern flank and along Ribeira Grande graben on the northern flank, reaching the sea in both cases (see distribution maps of the Fogo A ignimbrites in Pensa et al., 2015a, b).

The impact of PDCs on buildings and infrastructure is mostly related to their dynamic pressure and temperature. However, in this case we do not distinguish between dense and dilute currents and assumed a binary-impact approach, which considered the absence of damage or total destruction of buildings and infrastructure by PDCs. Ground and marine transportation networks are also highly vulnerable to PDCs as roads, ports and marinas would become buried or suffer irreparable heat damage. 


\subsection{Impact of explosive eruptions on the economy of tourism of Vila Franca do Campo}

The main economic activities in the Azores are public services, retail and wholesale trade, fishing, livestock ranching, and production of dairy products (Vieira et al., 2019). Tourism is a growing and promising activity for job creation and for the development of this archipelago, where the landscape and marine-related activities constitute the main attractions (Calado et al., 2011; Torres et al., 2017; Vieira and Antunes, 2017). From 2001 to 2018, there has been an almost constant increase in jobs related to tourism in the Azores. In 2015 tourism employed 11847 people, and in 2018 it reached 19614 people. These values give a good indication of the importance that this sector has assumed, growing to represent approximately $20 \%$ of all employment in the Azores (Fortuna et al., 2020). The number of visitors sharply expanded after the liberalisation of airspace in two corridors between the mainland and the Azores since 2015, which allowed the entrance of low-cost airlines (Vieira et al., 2019). According to satellite tourism accounts, tourism accounted for $6.7 \%$ of the gross value added (GVA). At the same time, the consumption of goods and services by tourists amounted to $14.1 \%$ of the GDP (SREA, 2018).

The location of Vila Franca do Campo municipality in the southern part of São Miguel Island, approximately $20 \mathrm{~km}$ east of Ponta Delgada city (the island's capital), together with its moderate climate and numerous bathing areas along the coast, attracts many tourists throughout the year. Therefore, tourism is a major source of revenue for this municipality. In 2018, the estimated total annual revenue of the accommodation units on Vila Franca do Campo was approximately EUR 9.5 million (assuming that the accommodation capacity would be fully occupied). This figure clearly shows the importance of this sector on the economy of the municipality and of the entire island of São Miguel.

Looking at the calculated LPV for a period of 30 years for each economic scenario, we can conclude that this value is greater when the occupancy rate is higher, and the discount rate is lower. Economic scenario 1 (tephra fallout from a VEI 4 sub-Plinian eruption during the summer period) has the smallest LPVs for the different rates used. The other two economic scenarios (PDCs from a VEI 4 sub-Plinian eruption and from a VEI 5 Plinian eruption) have similar LPVs because they comprise $96 \%$ and $98 \%$ of the accommodation buildings, respectively (Table 3 ). Still, and as expected, economic scenario 3 represents the higher loss, almost EUR 145 million (Table 4). As seen in Fig. 10, the LPV shows a decreasing trend over the years as a result of the applied methodology, except when the discount rate of $0 \%$ is applied as it causes LPV to remain constant over time.

The method used in this study is a first attempt to quantify the economic loss of the tourism sector resulting from future explosive eruptions of Fogo volcano. It should be noted that both the annual revenue and the LPV obtained for the tourism economy were estimated using only the values from the accommodation units of Vila Franca do Campo municipality. To achieve a more realistic estimation of the total revenue related to the tourism economy, the benefits of other sectors, such as restaurants or tourism animation and activities, should also be considered. The tourism industry also contributes to the economy by generating jobs in hotels, guest houses, local accommodations, restaurants, souvenir shops, etc., and therefore the workers' salaries should also be quantified. Indirect losses should also be accounted for, such as a drop in the consumption of fish, dairy or beef products in the food sector, thus affecting the economy of other sectors such as agriculture and sea. Nevertheless, the present methodology may be adopted to calculate the loss of revenue of other sectors related to tourism and also applied to different volcanic regions vulnerable to explosive volcanism.

\section{Conclusions}

This study presents a new approach to quantifying the impact of explosive volcanic eruptions on the tourism industry. We determined the economic loss related to future explosive eruptions of Fogo volcano (São Miguel Island) by estimating the benefits generated by the accommodation units of Vila Franca do Campo municipality.

Two eruptive scenarios were considered for Fogo volcano: the most probable scenario (a VEI 4 sub-Plinian eruption) and the worst-case scenario (a VEI 5 Plinian eruption). We evaluated the vulnerability of tourism-related buildings and infrastructure in Vila Franca do Campo to tephra fallout and PDCs by analysing their loss of functionality. The loss present value (LPV) method was used to estimate the benefits generated by the accommodation units for different economic scenarios.

The simulations show that tephra deposition from a VEI 4 sub-Plinian eruption during the summer period occurs to the east-south-east of Fogo caldera, while during the winter period the deposition is to the east of the caldera. For a VEI 5 Plinian eruption the dispersion patterns are similar but with a larger dispersion area and thicker tephra deposition. The simulations of PDCs show that the central part of São Miguel is the most affected as currents flow down the flanks of the volcano, reaching the sea on both coasts.

The assessment of the economic impact on the tourism sector shows that economic scenario 1 (tephra fallout from a VEI 4 sub-Plinian eruption) has the lowest LPV when compared to economic scenarios 2 and 3 (PDCs from VEI 4 sub-Plinian and VEI 5 Plinian eruptions, respectively), which have similar LPVs. Although economic scenario 3 is not the most likely as it represents near total destruction of Vila Franca do Campo municipality, it corresponds to the higher economic loss, with approximately EUR 145 million over 30 years. 
Tourism is a growing industry worldwide, and in the Azores it has had an increasing importance in the economy since 2015. However, the Azores and other active volcanic regions are vulnerable to future eruptions, which may have long-term economic consequences. Volcanic hazard and risk assessment is therefore essential in areas where people live side by side with active volcanoes in order to provide the competent authorities with appropriate strategies to mitigate volcanic risk, such as land use planning, emergency management and post-disaster economic recovery planning.

Data availability. Data used for the assessment of the economic impact can be made available by the corresponding author upon request. Wind data were obtained from the Integrated Global Radiosonde Archive of the National Centers for Environmental Information (formerly National Climatic Data Center).

Author contributions. JM was responsible for the investigation, conceptualisation, data curation, formal analysis, writing and preparing the manuscript with contributions from all co-authors. RC was responsible for the supervision, conceptualisation and project administration. AP was responsible for conceptualisation and supervision. JCV was responsible for the implementation of the economic methodology. GQ was responsible for the funding acquisition and project administration.

Competing interests. The authors declare that they have no conflict of interest.

Acknowledgements. The authors acknowledge the ERUPÇÃO project for funding this work. The authors also thank Dario Pedrazzi and an anonymous reviewer for the constructive comments that significantly improved the quality of this paper.

Financial support. This work was supported by the ERUPÇÃO project, financed by the Azores 2020 operational programme, funded by FEDER and the FSE Azores regional government (grant no. ACORES010145FEDER000016).

Review statement. This paper was edited by Sven Fuchs and reviewed by Dario Pedrazzi and one anonymous referee.

\section{References}

Aguiar, S.: Contribuição para o estudo da estratigrafia dos vulcões Fogo e Furnas (S. Miguel, Açores): implicações para a sua história eruptiva recente, MSc thesis, Universidade dos Açores, Portugal, 158 pp., 2018 (in Portuguese).

Alberico, I., Lirer, L., Petrosino, P., and Scandone, R.: A methodology for the evaluation of volcanic risk in Campi Flegrei, J.
Volcanol. Geoth. Res., 116, 6378, https://doi.org/10.1016/S03770273(02)00211-1, 2002.

Alberico, I., Lirer, L., Petrosino, P., and Scandone, R.: Volcanic hazard and risk assessment from pyroclastic flows at Ischia Island (Southern Italy), J. Volcanol. Geoth. Res., 171, 118136, https://doi.org/10.1016/j.jvolgeores.2007.11.014, 2008.

Alberico, I., Petrosino, P., and Lirer, L.: Volcanic hazard and risk assessment in a multi-source volcanic area: the example of Napoli city (Southern Italy), Nat. Hazards Earth Syst. Sci., 11, 10571070, https://doi.org/10.5194/nhess-11-1057-2011, 2011.

Alexander, D.: Volcanic ash in the atmosphere and risks for civil aviation: a study in European crisis management, Int. J. Disast. Risk Sc., 4, 919, https://doi.org/10.1007/s13753-013-0003-0, 2013.

Annen, C. and Wagner, J.: The impact of volcanic eruptions during the 1990s, Nat. Hazards Rev., 4, 169175, https://doi.org/10.1061/(ASCE)1527-6988(2003)4:4(169), 2003.

Blong, R. J.: Volcanic hazards, Academic Press, Australia, 424 pp., 1984.

Booth, B., Croasdale, R., and Walker, G. P. L.: A quantitative study of five thousand years of volcanism on S. Miguel, Azores, Philos. T. R. Soc. A., 228, 271319, https://doi.org/10.1098/rsta.1978.0018, 1978.

Brown, S. K., Jenkins, S. F., Sparks, R. S. J., Odbert, H., and Auker, M. R.: Volcanic fatalities database: analysis of volcanic threat with distance and victim classification, J. Appl. Volcanol., 6, 15, https://doi.org/10.1186/s13617-017-0067-4, 2017.

Bursik, M. I., Sparks, R. S. J., Gilbert, G. S., and Carey, S. N.: Sedimentation of tephra by volcanic plumes: I. Theory and its comparison with a study of the Fogo A plinian deposit, Sao Miguel (Azores), B. Volcanol., 54, 329344, https://doi.org/10.1007/BF00301486, 1992.

Cabral, J.: Avaliação dos perigos vulcânicos e fenómenos associados na Ilha do Fogo (Cabo Verde): implicações para o planeamento de emergência e ordenamento do território, $\mathrm{PhD}$ thesis, Universidade dos Açores, Portugal, 281 pp., 2015 (in Portuguese).

Calado, H., Ng, K., Borges, P., Alves, F., and Sousa, L.: Climate change and coastal tourism in the Azores archipelago, in: Disappearing Destinations: Climate Change and the $\mathrm{Fu}-$ tures Challenges for Coastal Tourism, edited by: Jones, A. J. and Phillips, M., CAB Intl, Wallingford, 111-124, https://doi.org/10.1079/9781845935481.0111, 2011.

Carey, S. and Sparks, R. S. J.: Quantitative models of the fallout and dispersal of tephra from volcanic eruption columns, B. Volcanol., 48, 109-125, https://doi.org/10.1007/BF01046546, 1986.

Clare, M. A., Le Bas, T., Price, D. M., Hunt, J. E., Sear, D., Cartigny, M. J. B., Vellinga, A., Symons, W., Firth, C., and Cronin, S.: Complex and cascading triggering of submarine landslides and turbidity currents at volcanic islands revealed from integration of high-resolution onshore and offshore surveys, Front. Earth Sci., 6, 223, https://doi.org/10.3389/feart.2018.00223, 2018.

Cole, P. D., Queiroz, G., Wallenstein, N., Gaspar, J. L., Duncan, A. M., and Guest, J. E.: An historic subplinian/phreatomagmatic eruption: the $1630 \mathrm{AD}$ eruption of Furnas volcano, São Miguel, Azores, J. Volcanol. Geoth.. Res., 69, 117-135, https://doi.org/10.1016/0377-0273(95)00033-X, 1995. 
Cole, P. D., Pacheco, J. M., Gunasekera, R., Queiroz, G., Gonçalves, P., and Gaspar, J. L.: Contrasting styles of explosive eruption at Sete Cidades, São Miguel, Azores, in the last 5000 years: hazard implications from modelling, J. Volcanol. Geoth. Res., 178, 574591, https://doi.org/10.1016/j.jvolgeores.2008.01.008, 2008.

Courard-Hauri, D., Klimas, C., and Parrish, C.: An analysis of the long-term social discount rate and the valuation of large environmental losses using non-monetary tradeoffs, J. Behav. Exp. Econ., 87, 101549, https://doi.org/10.1016/j.socec.2020.101549, 2020.

Craig, H., Wilson, T., Stewart, C., Outes, V., Villarosa, G., and Baxter, P.: Impacts to agriculture and critical infrastructure in Argentina after ashfall from the 2011 eruption of the Cordón Caulle volcanic complex: an assessment of published damage and function thresholds, J. Appl. Volcanol., 5, 7, https://doi.org/10.1186/s13617-016-0046-1, 2016.

EMODnet Bathymetry Consortium: EMODnet Digital Bathymetry (DTM), The GEBCO_08 Grid, version 20100927, https://doi.org/10.12770/18ff0d48-b203-4a6594a9-5fd8b0ec35f6, 2018.

Evans, D. J. and Sezer, H.: Social discount rates for six major countries, Appl. Econ. Lett., 11, 557560, https://doi.org/10.1080/135048504200028007, 2004.

Evans, D. J. and Sezer, H.: Social discount rates for member countries of the European Union, J. Econ. Stud., 32, 4759, https://doi.org/10.1108/01443580510574832, 2005.

Felpeto, A., Marti, J., and Ortiz, R.: Automatic GIS-based system for volcanic hazard assessment, J. Volcanol. Geoth. Res., 166, 106116, https://doi.org/10.1016/j.jvolgeores.2007.07.008, 2007.

Folch, A. and Felpeto, A.: A coupled model for dispersal of tephra during sustained explosive eruptions, J. Volcanol. Geoth. Res., 145, 337349, https://doi.org/10.1016/j.jvolgeores.2005.01.010, 2005.

Florio, M.: Cost-benefit analysis and the European union cohesion fund: On the social cost of capital and labour, Reg. Stud., 40, 211-224, https://doi.org/10.1080/00343400600600579, 2006.

Florio, M. and Sirtori, E.: The social cost of capital: recent estimates for the EU countries, Working Paper 201303, CSIL Milano, Centre for Industrial Studies, https://doi.org/10.2139/ssrn.2723379, 2013.

Fortuna, M., Vieira, J. C., and Maciel, R.: Estimação do Emprego no Turismo: Uma Abordagem com Contas Satélite, in: O Turismo na Economia dos Açores: Do Arranque do Século XXI à Pandemia de 2020, edited by: Fortuna, M. and Maciel, R., Centro de Estudos de Economia Aplicada do Atlântico - CEEAplA, ISBN: 978-989-8870-31-5, 143-163, 2020 (in Portuguese).

Frutuoso, G.: Livro Quarto das Saudades da Terra, in: Saudades da Terra, edited by: Frutuoso, G., 2nd edition, Instituto Cultural de Ponta Delgada, Ponta Delgada, 1522-1591, 1981 (in Portuguese).

Gaspar, J. L., Goulart, C., Queiroz, G., Silveira, D., and Gomes, A.: Dynamic structure and data sets of a GIS database for geological riskanalysis in the Azores volcanic islands, Nat. Hazards Earth Syst. Sci., 4, 233-242, https://doi.org/10.5194/nhess4-233-2004, 2004.

Gaspar, J. L., Guest, J. E., Queiroz, G., Pacheco, J., Pimentel, A., Gomes, A., Marques, R., Felpeto, A., Ferreira, T., and Wallenstein, N.: Eruptive frequency and volcanic hazards zonation in São Miguel Island, Azores, in: Volcanic Geology of
São Miguel Island (Azores Archipelago), Memoirs, 44, edited by: Gaspar, J. L., Guest, J. E., Duncan, A. M., Barriga, F. J. A. S., and Chester, D. K., Geological Society, London, https://doi.org/10.1144/M44.12, 2015a.

Gaspar, J. L., Queiroz, G., Ferreira, T., Medeiros, A. R., Goulart, C., and Medeiros, J.: Earthquakes and volcanic eruptions in the Azores region: geodynamic implications from major historical events and instrumental seismicity, in: Volcanic Geology of São Miguel Island (Azores Archipelago), edited by: Gaspar, J. L., Guest, J. E., Duncan, A. M., Barriga, F. J. A. S., and Chester, D. K., Geological Society, London, https://doi.org/10.1144/M44.4, 2015b.

Gasteiger, J., Groß, S., Freudenthaler, V., and Wiegner, M.: Volcanic ash from Iceland over Munich: mass concentration retrieved from ground-based remote sensing measurements, Atmos. Chem. Phys., 11, 2209-2223, https://doi.org/10.5194/acp11-2209-2011, 2011.

Gomes, A., Gaspar, J. L., and Queiroz, G.: Seismic vulnerability of dwellings at Sete Cidades Volcano (S. Miguel Island, Azores), Nat. Hazards Earth Syst. Sci., 6, 41-48, https://doi.org/10.5194/nhess-6-41-2006, 2006.

Gudmundsson, M. T., Thordarson, T., Höskuldsson, A., Larsen, G., Björnsson, H., Prata, F. J., Oddsson, B., Magnússon, E., Högnadóttir, T., Petersen, G. N., Hayward, C. L., Stevenson, J. A., and Jónsdóttir, I.: Ash generation and distribution from the April-May 2010 eruption of Eyjafjallajökull, Iceland, Sci. Rep.UK, 2, 572, https://doi.org/10.1038/srep00572, 2012.

Guffanti, M., Ewert, J. W., Swanson, G., Gallina, G., and Bluth, G.: The volcanic-ash hazard to aviation during the 2003-2004 eruptive activity of Anatahan volcano, Commonwealth of the Northern Mariana Islands, J. Volcanol. Geoth. Res., 146, 241255, https://doi.org/10.1016/j.jvolgeores.2004.12.011, 2005.

Hansen, J., Lacis, A., Ruedy, R., and Sato, M.: Potential climate impact of Mount Pinatubo eruption, Geophys. Res. Lett., 19, 215218, https://doi.org/10.1029/91GL02788, 1992.

Hernández, A., Kutiel, H., Trigo, R. M., Valente, M. A., Sigró, J., Cropper, T., and Santo, F. E.: New Azores archipelago daily precipitation dataset and its links with large-scale modes of climate variability, Int. J. Climatol., 36, 4439-4454, https://doi.org/10.1002/joc.4642, 2016.

Hicks, A. and Few, R.: Trajectories of social vulnerability during the Soufrière Hills volcanic crisis, J. Appl. Volcanol., 4, 10, https://doi.org/10.1186/s13617-015-0029-7, 2015.

Hipólito, A., Madeira, J., Gaspar, J. L., and Carmo, R.: Neotectónica da ilha Graciosa - uma contribuição para o enquadramento geodinâmico da junção tripla dos Açores, e-Terra, Revista electrónica das Ciências da Terra, 11, 3, ISSN 1645-0388, 2010 (in Portuguese).

Jónsdóttir, A.: Impact of Eyjafjallajökull on tourism and internacional flights, BSc thesis, Líf-ogumhverfisvísindadeild, Verkfræði-ognáttúruvísindasvið, HáskóliÍslands, Reykjavík, Iceland, 57 pp., 2011.

Kokelaar, B.: Setting, chronology and consequences of the eruption of Soufrière Hills Volcano, Montserrat (19951999), in: The Eruption of Soufrière Hills Volcano, Montserrat, from 1995 to 1999, edited by: Druitt, T. H. and Kokelaar, B. P., Geological Society, London, https://doi.org/10.1144/GSL.MEM.2002.021.01.02, 2002. 
Kueppers, U., Pimentel, A., Ellis, B., Forni, F., Neukampf, J., Pacheco, J., Perugini, D., and Queiroz, G.: Biased volcanic hazard assessment due to incomplete eruption records on ocean islands: an example of Sete Cidades Volcano, Azores, Front. Earth Sci., 7, 122, https://doi.org/10.3389/feart.2019.00122, 2019.

Malin, M. C. and Sheridan, M. F.: Computer-assisted mapping of pyroclastic surges, Science, 217, 637640, https://doi.org/10.1126/science.217.4560.637, 1982.

Newhall, C. G. and Self, S.: The Volcanic Explosivity Index (VEI): an estimate of explosive magnitude for historical volcanism, J. Geophys. Res., 87, 12311238, https://doi.org/10.1029/JC087iC02p01231, 1982.

Official Journal of the European Union: Commission notice on current State aid recovery interest rates and reference/discount rates for 25 Member States applicable as from 1 January 2007 Published in accordance with Article 10 of Commission Regulation (EC) 794/2004 of 21 April 2004 (OJ L 140, 30.4.2004, p. 1) and the Commission notice on the method for setting the reference and discount rates (OJ C 273, 9.9.1997, p. 3), OJ C 317, 23.12.2006: 22 (ES, CS, DA, DE, ET, EL, EN, FR, IT, LV, LT, HU, NL, PL, PT, SK, SL, FI, SV), 2006.

Oxford Economics: The economic impacts of air travel restrictions due to volcanic ash, A report prepared for Airbus, 12 pp., available at: https://www.oxfordeconomics.com/my-oxford/projects/ 129051 (last access: 23 July 2020), 2010.

Pacheco, G. B. and Lewis-Cameron, A.: Weathering the storm - crisis marketing for small island tourist destinations, in: Marketing island destinations, edited by: Lewis-Cameron, A. and Roberts, S., Elsevier, London, 2010.

Pacheco, J. M., Ferreira, T., Queiroz, G., Wallenstein, N., Coutinho, R., Cruz, J. V., Pimentel, A., Silva, R., Gaspar, J. L., and Goulart, C.: Notas sobre a Geologia do Arquipélago dos Açores, in: Geologia de Portugal, Vol. 2, edited by: Dias, R., Araújo, A., Terrinha, P., and Kullberg, J. C., Escolar Editora, Vila Franca de Xira, 2013 (in Portuguese).

Pallister, J. and McNutt, S. R.: Synthesis of Volcano Monitoring, in: The Encyclopedia of Volcanoes, Second Edition, edited by: Sigurdsson, H., Houghton, B. F., McNutt, S. R., Rymer, H., and Stix, J., Academic Press, London, https://doi.org/10.1016/B9780-12-385938-9.00066-3, 2015.

Pálsson, T.: Atlantic Conference on Eyjafjallajökull and Aviation - Conference Summary and Conclusions, Keilir Aviation Academy, Keflavik Airport, Iceland, 15-16 September 2010, 2010.

Pelling, M. and Uitto, J. I.: Small island developing states: natural disaster vulnerability and global change, Global Environmental Change Part B: Environ. Hazards, 3, 4962, https://doi.org/10.1016/S1464-2867(01)00018-3, 2001.

Pensa, A., Cas, R., Giordano, G., Porreca, M., and Wallenstein, N.: Transition from steady to unsteady Plinian eruption column: the VEI 5, $4.6 \mathrm{ka}$ Fogo A Plinian eruption, São Miguel, Azores, J. Volcanol. Geoth. Res., 305, 118, https://doi.org/10.1016/j.jvolgeores.2015.09.012, 2015a.

Pensa, A., Giordano, G., Cas, R., and Porreca, M.: Thermal state and implications for eruptive styles of the intraPlinian and climactic ignimbrites of the $4.6 \mathrm{ka}$ Fogo A eruption sequence, São Miguel, Azores, B. Volcanol., 77, 99, https://doi.org/10.1007/s00445-015-0983-2, 2015b.
Pimentel, A., Pacheco, J. M., and Felpeto, A.: Influence of wind patterns on the dispersal of volcanic plumes in the Azores region: test study of the 1630 eruption of Furnas Volcano (S. Miguel, Azores), EGU General Assembly, Vienna, Austria, 2-7 April 2006, EGU06-A-04983, 2006.

Pimentel, A., Pacheco, J., and Self, S.: The $~ 1000$-years BP explosive eruption of Caldeira volcano (Faial. Azores): the first stage of incremental caldera formation, B. Volcanol., 77, 42, https://doi.org/10.1007/s00445-015-0930-2, 2015.

Pimentel, A., Ramalho, R. S., Becerril, L., Larrea, P., and Brown, R. J.: Editorial: ocean island volcanoes: genesis, evolution and impact, Front. Earth Sci., 8, 82, https://doi.org/10.3389/feart.2020.00082, 2020.

Pomonis, A., Spence, R., and Baxter, P.: Risk assessment of residential buildings for an eruption of Furnas volcano, São Miguel, the Azores, J. Volcanol. Geoth. Res., 92, 107131, https://doi.org/10.1016/S0377-0273(99)00071-2, 1999.

Rampino, M. R. and Self, S.: Historic eruptions in Tambora (1815), Krakatau (1883), and Agung (1963), their stratospheric aerosols, and climatic impact, Quaternary Res., 18, 127143, https://doi.org/10.1016/0033-5894(82)90065-5, 1982.

Scaini, C., Biass, S., Galderisi, A., Bonadonna, C., Folch, A., Smith, K., and Höskuldsson, A.: A multi-scale risk assessment for tephra fallout and airborne concentration from multiple Icelandic volcanoes - Part 2: Vulnerability and impact, Nat. Hazards Earth Syst. Sci., 14, 2289-2312, https://doi.org/10.5194/nhess14-2289-2014, 2014.

Silva, R., Havskov, J., Bean, C., and Wallenstein, N.: Seismic swarms, fault plane solutions and stress tensors for São Miguel Island central region (Azores), J. Seismol., 16, 389-407, https://doi.org/10.1007/s10950-012-9275-x, 2012.

Silva, R., Ferreira, T., Medeiros, A., Carmo, R., Luís, R., Wallenstein, N., and Sousa, R.: Seismic activity on S. Miguel Island volcano-tectonic structures (Azores archipelago), in: Volcanic Geology of São Miguel Island (Azores Archipelago), edited by: Gaspar, J. L., Guest, J. E., Duncan, A. M., Barriga, F. J. A. S., and Chester, D. K., Geological Society, London, 227-238, https://doi.org/10.1144/M44.17, 2015.

Silva, R., Carmo, R., and Marques, R.: Characterization of the tectonic origins of historical and modern seismic events and their societal impact on the Azores Archipelago, Portugal, Geol. Soc. Spec. Publ., 501, 106, https://doi.org/10.1144/SP501-2019-106, 2020.

Spence, R. J. S., Kelman, I., Baxter, P. J., Zuccaro, G., and Petrazzuoli, S.: Residential building and occupant vulnerability to tephra fall, Nat. Hazards Earth Syst. Sci., 5, 477-494, https://doi.org/10.5194/nhess-5-477-2005, 2005.

SREA: Conta Satélite do Turismo da Região Autónoma dos Açores - 2015, Destaque, Open File Rep., 1-9, available at: https://srea. azores.gov.pt/ (last access: 9 July 2020), 2018 (in Portuguese).

Suzuki, T.: A theoretical model for dispersion of tephra, in: Arc volcanism: physics and tectonics, edited by: Shimozuru, D. and Yokoyama, I., Terra Scientific Publishing Company, Tokyo, 1983.

Torres, P., Bulhão, N., da Cunha, R., Vieira, J., and Rodrigues, A.: Dead or alive: the growing importance of shark diving in the Mid-Atlantic region, J. Nat. Conserv., 36, 20-28, https://doi.org/10.1016/j.jnc.2017.01.005, 2017. 
Toyos, G. P., Cole, P. D., Felpeto, A., and Martí, J.: A GIS-based methodology for hazard mapping of small pyroclastic density currents, Nat. Hazards, 41, 99112, https://doi.org/10.1007/s11069-006-9026-9, 2007.

Vianna, G. M. S., Meekan, M. G., Pannell, D. J., Marsh, S. P., and Meeuwig, J. J.: Socio-economic value and community benefits from shark-diving tourism in Palau: a sustainable use of reef shark populations, Biol. Conserv., 145, 267277, https://doi.org/10.1016/j.biocon.2011.11.022, 2012.

Vieira, J. C. and Antunes, M. C.: Touristic big-game fishing in Saint Michael Island (Azores): evaluating anglers' profiles, perceptions about the destination and business revenues, Tourism Econ., 23, 1362-1368, https://doi.org/10.1177/1354816616686414, 2017.

Vieira, J., Câmara, G., Silva, F., and Santos, C.: Airline choice and tourism growth in the Azores, J. Air Transp. Manag., 77, 1-6, https://doi.org/10.1016/j.jairtraman.2019.02.009, 2019.

Viveiros, F., Gaspar, J. L., Ferreira, T., Silva, C., Marcos, M., Hipólito, A.: Mapping of soil $\mathrm{CO}_{2}$ diffuse degassing at São Miguel Island and its public health implications, in: Volcanic Geology of São Miguel Island (Azores Archipelago), edited by: Gaspar, J. L., Guest, J. E., Duncan, A. M., Barriga, F. J. A. S., and Chester, D. K., Geological Society, London, https://doi.org/10.1144/M44.14, 2015.

Wadge, G., Voight, B., Sparks, R. S. J., Cole, P. D., Loughlin, S. C., and Robertson, R. E. A.: An overview of the eruption of Soufrière Hills Volcano, Montserrat form 2000 to 2010, in: The Eruption of Soufrière Hills Volcano, Montserrat from 2000 to 2010, edited by: Wadge, G., Robertson, R. E. A., and Voight, B., Geological Society, London, https://doi.org/10.1144/M39.1, 2014.

Walker, G. P. L. and Croasdale, R.: Two plinian-type eruptions in the Azores, J. Geol. Soc. London, 127, 17-55, https://doi.org/10.1144/gsjgs.127.1.0017, 1971.
Wallenstein, N.: Estudo da história recente e do comportamento eruptivo do vulcão do Fogo (S. Miguel, Açores), Avaliação preliminar do "hazard", PhD thesis, Universidade dos Açores, Portugal, 266 pp., 1999 (in Portuguese).

Wallenstein, N., Duncan, A., Chester, D. K., and Marques, R.: Fogo Volcano (São Miguel, Azores): a hazardous Edifice, Geomorphologie, 3, 259-270, https://doi.org/10.4000/geomorphologie.2853, 2007.

Wallenstein, N., Duncan, A., Guest, J. E., and Almeida, M. H.: Eruptive history of Fogo Volcano, São Miguel, Azores, in: Volcanic Geology of São Miguel Island (Azores Archipelago), edited by: Gaspar, J. L., Guest, J. E., Duncan, A. M., Barriga, F. J. A. S., and Chester, D. K., Geological Society, London, https://doi.org/10.1144/M44.8, 2015.

Wilson, G., Wilson, T. M., Deligne, N. I., and Cole, J. W.: Volcanic hazard impacts to critical infrastructure: a review, J. Volcanol. Geoth. Res., 286, 148182, https://doi.org/10.1016/j.jvolgeores.2014.08.030, 2014.

Wilson, L. and Huang, T. C.: The influence of shape on the atmospheric settling velocity of volcanic ash particles, Earth Planet. Sc. Lett., 44, 311-324, https://doi.org/10.1016/0012821X(79)90179-1, 1979.

Wilson, T. M., Stewart, C., Sword-Daniels, V., Leonhard, G. S., Johnston, D. M., Cole, J. W., Wardman, J., Wilson, G., and Barnard, S. T.: Volcanic ash impacts on critical infrastructure, Phys. Chem. Earth, 4, 523, https://doi.org/10.1016/j.pce.2011.06.006, 2012. 